NBER WORKING PAPER SERIES

\title{
RACIAL DIVERSITY AND RACIAL POLICY PREFERENCES: THE GREAT MIGRATION AND CIVIL RIGHTS
}

\author{
Alvaro Calderon \\ Vasiliki Fouka \\ Marco Tabellini \\ Working Paper 28965 \\ http://www.nber.org/papers/w28965 \\ NATIONAL BUREAU OF ECONOMIC RESEARCH \\ 1050 Massachusetts Avenue \\ Cambridge, MA 02138 \\ June 2021
}

\begin{abstract}
We thank Alberto Alesina, Sam Bazzi, Leah Boustan, Davide Cantoni, Melissa Dell, Ryan Enos, Silvia Farina, Nicola Fontana, Jeff Frieden, Nicola Gennaioli, Luigi Guiso, Petra Moser, Markus Nagler, Gerard Padro i Miquel, John Parman, Torsten Persson, Vincent Pons, Jim Snyder, Evan Taylor, Gaspare Tortorici, Nico Voigtlaender, Matt Weinzierl, Gavin Wright and seminar participants at Berkeley, Bocconi, Bologna, CEMFI, CGM Pitt Race and Identity Seminar, George Mason, EIEF, Harvard, LMU, LSE, Northwestern Economic History Lunch, Nottingham, PSE Migration Seminar, Rochester, Stanford, UBC, UCSD, UPF, Virtual Seminars in Economic History, Warwick, the Atlanta 2019 EHA Annual Meetings, the Galatina Summer Meetings, the 2021 ERINN Conferences, the Tilburg Symposium on Social Cohesion, the Yale Politics and History Conference, and the 2020 Virtual World Congress of the Econometric Society for useful comments. We are grateful to Eric Schickler and Kathryn Pearson for sharing with us data on signatures on discharge petitions, and to James Gregory for sharing datasets on NAACP presence and CORE non-violent demonstrations. Silvia Farina, Ludovica Mosillo, Monia Tomasella, Francesca Bramucci, Pier Paolo Creanza, Martina Cuneo, Federico Mattei, Sarah O'Brein, Gisela Salim Peyer, Federico Scabbia, and Arjun Shah provided excellent research assistance. The views expressed herein are those of the authors and do not necessarily reflect the views of the National Bureau of Economic Research.
\end{abstract}

NBER working papers are circulated for discussion and comment purposes. They have not been peer-reviewed or been subject to the review by the NBER Board of Directors that accompanies official NBER publications.

(C) 2021 by Alvaro Calderon, Vasiliki Fouka, and Marco Tabellini. All rights reserved. Short sections of text, not to exceed two paragraphs, may be quoted without explicit permission provided that full credit, including $(\odot$ notice, is given to the source. 
Racial Diversity and Racial Policy Preferences: The Great Migration and Civil Rights Alvaro Calderon, Vasiliki Fouka, and Marco Tabellini NBER Working Paper No. 28965

June 2021

JEL No. D72,J15,N92

\begin{abstract} lines on racial issues.

Alvaro Calderon

Department of Economics

Stanford University

579 Jane Stanford Way

Stanford, CA 94305

acald@nber.org

Vasiliki Fouka

Stanford University

Department of Political Science

616 Jane Stanford Way

Stanford, CA 94305

and CEPR

and also NBER

vfouka@stanford.edu

Marco Tabellini

Harvard Business School

279 Morgan Hall

Soldiers Field Road

Boston, MA 02163

and CEPR

mtabellini@hbs.edu
\end{abstract}

Between 1940 and 1970, more than 4 million African Americans moved from the South to the North of the United States, during the Second Great Migration. This same period witnessed the struggle and eventual success of the civil rights movement in ending institutionalized racial discrimination. This paper shows that the Great Migration and support for civil rights are causally linked. Predicting Black inflows with a shift-share instrument, we find that the Great Migration increased support for the Democratic Party and encouraged pro-civil rights activism in northern and western counties. These effects were not only driven by Black voters, but also by progressive and working class segments of the white population. We identify the salience of conditions prevailing in the South, measured through increased reporting of southern lynchings in northern newspapers, as a possible channel through which the Great Migration increased whites' support for civil rights. Mirroring the changes in the electorate, non-southern Congress members became more likely to promote civil rights legislation, but also grew increasingly polarized along party 


\section{Introduction}

Racial inequality is a pervasive feature of US society, encompassing most of its domains - from earnings to employment opportunities, from intergenerational mobility to incarceration rates. ${ }^{1}$ One of the potential causes of the racial gap and of its unwavering persistence is the lack of political empowerment of Black Americans who, for a major part of American history, have been denied even the most fundamental civil right in a democracy, namely the right to vote. Black political oppression was particularly strong in the US South. Writing in 1944, Swedish economist and Nobel Prize winner Gunnar Myrdal argued that migrating outside the region represented the most effective strategy for Black Americans to achieve racial equality and finally gain political rights (Myrdal, 1944). According to Myrdal, "[t]he average Northerner does not understand the reality and the effects of such [Southern] discriminations", and "[t]o get publicity is of the highest strategic importance to [Blacks]".

Around the time of Myrdal's statement, many African Americans had already started to move from the South to the North and West of the US, hoping to reach a "Promised Land" (Boustan, 2016) and to leave behind them the system of disenfranchisement, violence, and discrimination perpetuated by the infamous Jim Crow laws. Eventually, more than 4 million Black Americans migrated between 1940 and 1970 in what is known as the Second Great Migration (henceforth, Great Migration).

The Great Migration temporally coincided with the development and eventual success of the civil rights movement - a turning point in the history of race relations, which culminated in the passage of the Civil and Voting Rights Acts of 1964 and 1965. Given the resistance of southern politicians to extend the franchise to Black Americans, northern legislators and grassroots organizations based in the North, such as the National Association for the Advancement of Colored People (NAACP) and the Congress of Racial Equality (CORE), played a key role in the process of enfranchisement (Lawson, 1976). Was Myrdal right? Did northward migration allow African Americans to gain political power?

In this paper, we study this question, analyzing the political effects of Black inmigration to the US North and West between 1940 and 1970. First, we examine how the Great Migration affected demand for civil rights and racial equality among northern

\footnotetext{
${ }^{1}$ See, among others, recent works by Bayer and Charles (2018) and Chetty et al. (2020). Previous important contributions on this topic include Smith and Welch (1989) and Neal and Johnson (1996). See also the review in Altonji and Blank (1999).
} 
voters. We measure support for civil rights in several ways, but use as main proxies the Democratic vote share in Congressional elections and the frequency of non-violent pro-civil rights demonstrations organized by grassroots organizations in the North. Even though the Democratic Party was openly segregationist and stubbornly defended white supremacy in the South until the early 1960s (Kuziemko and Washington, 2018; Lawson, 1976), by the end of the 1930s in the North and West it had unambiguously become the party defending Black people's interests and pushing for racial equality (Schickler, 2016; Wasow, 2020). ${ }^{2}$ Second, we analyze the effects of Black in-migration on the ideology and behavior of members of the House on race-related issues.

The political effects of the Great Migration are far from obvious. On the one hand, recent work in economics has documented that the Great Migration had substantial negative effects on African Americans in the long run. Black in-migration to northern cities increased racial residential segregation, as white residents fled urban areas for the suburbs (Boustan, 2010). In turn, whites' residential choices, coupled with changes in the allocation of local public goods away from education and towards policing, drastically limited opportunities for economic and social mobility of African Americans (Derenoncourt, 2018). Racial residential segregation and lower economic opportunities may have been accompanied by whites' political backlash, which reduced Black Americans' political efficacy.

On the other hand, the Great Migration might have promoted Black Americans' political empowerment for at least two reasons. First, around 1940, Black individuals were de facto or de jure prevented from voting in most southern states (Cascio and Washington, 2014), whereas no restrictions to their political participation existed in the North. The inflow of Black voters may have thus shifted northern politicians' incentives to introduce civil rights legislation. Second, Black arrivals may have moved the preferences of at least some white voters in a more liberal direction. This might have happened either because the Great Migration increased whites' awareness of the conditions prevailing in the South, as envisioned by Myrdal (1944), or because progressive segments of the Democratic coalition saw an opportunity to jointly promote racial equality and economic goals by forming a cross-race alliance, as suggested by the political science literature (Adams, 1966; Frymer and Grumbach, 2020; Schickler, 2016).

\footnotetext{
${ }^{2}$ Below, we corroborate this idea providing evidence consistent with the existing literature (Feinstein and Schickler, 2008; Schickler, 2016). On party realignment during this historical period, see also Caughey et al. (2020).
} 
To study the political effects of the Great Migration we estimate stacked first difference regressions, controlling for state time-varying unobservable characteristics, and allowing counties to be on differential trends depending on their initial Black share and political conditions. To further account for potentially endogenous migration, we construct a version of the shift-share instrument (Card, 2001; Boustan, 2010) that assigns Black outflows from each southern state to northern counties based on pre-existing settlements of African Americans outside the South.

The shift-share instrument combines two separate sources of variation. First, it leverages time-series variation in Black emigration rates from different southern states for each decade between 1940 and 1970. Second, it allocates those southern outflows to northern counties based on the "mix" - in terms of southern state composition - of Black individuals living there in 1940. Since we always condition on the 1940 Black share of the population, the instrument only exploits variation in the composition of Black migrants across southern states over time.

Several recent papers discuss identification in shift-share designs (Adao et al., 2019; Borusyak et al., 2021; Goldsmith-Pinkham et al., 2020; Jaeger et al., 2018). As formalized in Borusyak et al. (2021), a large number of shocks across southern counties that are orthogonal to the evolution of the political landscape in northern counties would represent a sufficient condition for the shift-share instrument to be valid. We construct versions of the instrument for which these conditions are likely to hold, and show that our results are unchanged when using these alternative designs.

First, as in Boustan (2010), we exploit only variation in local push factors across southern counties to predict Black outflows from the South. ${ }^{3}$ Second, similar to Derenoncourt (2018), we construct a version of the instrument based on a linked sample of Black migrants between 1910 and 1930 from Abramitzky et al. (2020), which allows us to use a county-to-county migration matrix to construct "initial shares" for early Black residents in the US North. This instrument rests on variation in predicted migration - based on factors plausibly exogenous to political change in northern counties - from more than 1,200 southern counties. ${ }^{4}$

The alternative push instruments just described also mitigate concerns that pull shocks in northern counties both influenced the local political landscape and caused

\footnotetext{
${ }^{3}$ Examples of such plausibly exogenous push shocks are WWII spending or the mechanization of cotton, which occurred in the 1950s and impacted southern counties differentially depending on their 1940 cotton acreage.

${ }^{4}$ This strategy also assuages potential concerns over serial correlation in migration flows from the same location to the same destination (Jaeger et al., 2018).
} 
out-migration from southern states that already had large enclaves in those counties before 1940. We provide further evidence against this idea in two ways. First, we show that the instrument is uncorrelated with WWII spending and New Deal relief programs (Boustan et al., 2010; Boustan, 2016). Second, we replicate the analysis separately controlling for a measure of labor demand predicted using the 1940 industry composition of northern counties.

We conduct a number of additional robustness checks to address the possibility that the characteristics of northern areas where a different mix of southern born African Americans settled before 1940 had persistent effects both on changes in racial attitudes and on migration patterns (Goldsmith-Pinkham et al., 2020). First, we document that the instrument is not correlated with the pre-1940 change in political conditions across northern counties. Second, we allow counties to be on differential trends by interacting period dummies with several 1940 local characteristics, such as the Black and the urban share of the population, initial support for the Democratic Party, distance from the Mason-Dixon line, geographic coordinates, and the employment share in manufacturing.

Given existing evidence that the Great Migration caused "white flight" (Boustan, 2010; Shertzer and Walsh, 2019), we verify that Black inflows did not lead to white out-migration or to changes in the composition of white residents at the county level. These results are not in contrast with previous work (Boustan, 2010). Since county boundaries do not overlap with city-suburbs divides, and counties often include both central cities and suburban rings, changes in population triggered by Black inflows occurred within (and not between) the jurisdictions considered in our analysis.

Turning to our main results, we find that Black in-migration had a strong, positive impact on the Democratic vote share in Congressional elections. Our estimates imply that one percentage point increase in the Black share raised the Democratic vote share by 1.8 percentage points, or $4 \%$ relative to the 1940 mean. This is a large effect: even under the aggressive assumption that all Black migrants immediately voted for the Democratic Party upon arrival, support for the Democrats must have increased among northern residents because of Black inflows. Complementing our electoral results, we find that Black arrivals increased both the frequency of non-violent pro-civil rights demonstrations organized by CORE and the presence of local NAACP chapters.

Consistent with the view that African Americans were quickly incorporated in the political life of northern cities (Moon, 1948), we find that Black in-migration had a 
positive but quantitatively small impact on turnout. This indicates that Black inflows likely induced existing voters to switch away from the GOP. Since not all Black residents were already voting for the Democratic Party in the early 1940s, some switchers were African Americans. However, the magnitude of our estimates implies that some segments of the white electorate likely joined the Democratic voting bloc as well. Using a subset of the data on pro-civil rights demonstrations, which reports the race of participants, we indeed find that not only Black but also white individuals joined pro-civil rights demonstrations.

We provide additional, suggestive evidence that Black in-migration increased support for civil rights among northern whites by using historical survey data. State level cross-sectional regressions reveal that, in the years preceding the 1964 Civil Rights Act (CRA), white respondents living in states that received more Black migrants between 1940 and 1960 held more favorable views on race relations, considered racial equality as one of the most fundamental issues for the country, and were more likely to vote for the Democratic Party.

To understand which segments of the white electorate became more supportive of civil rights, we explore heterogeneity patterns in our results. Focusing on pro-civil rights demonstrations, we exploit variation in county 1940 composition and historical characteristics. First, we document that CORE demonstrations were more frequent where the share of whites employed in manufacturing was higher, where the presence of the Congress of Industrial Organizations (CIO) - the main force behind industrial unionism - was stronger, and where elections were more competitive. These places may have offered fertile grounds for the formation of a liberal cross-race coalition along political and economic lines, as discussed extensively in Schickler (2016). Consistent with labor unions supporting a cross-race coalition only, or especially, when labor markets were tight (Bailer, 1944), pro-civil rights demonstrations occurred only where labor demand, predicted using a Bartik-style approach, was stronger.

Second, we consider the possibility that the Great Migration raised support for civil rights among socially progressive whites by increasing the salience of the "race problem" and activating their latent demand for racial equality (Allport, 1954; Myrdal, 1944). We document that pro-civil rights demonstrations were concentrated in counties with a history of lower racial discrimination. Dippel and Heblich (2021) show that the presence of the Forty-Eighters - socialist leaders expelled from Germany to the US after the failed revolution of 1848-1849 - had long-lasting effects on support for civil rights 
and racial equality. We find that CORE demonstrations increased more in counties closer to the cities where the Forty-Eighters initially settled, where one would expect Black arrivals to induce a stronger sensitization of the white electorate.

To more rigorously test the "information mechanism" envisioned by Myrdal (1944), we compiled the list of all known lynchings committed by white offenders against Black Americans in the US South between 1940 and 1964. Then, we searched for such episodes in local newspapers of non-southern counties, identifying them with the joint mention of the name of the victim and the place of the lynching. By conducting a series of event studies, we document that, in the weeks following a lynching, northern local newspapers were more likely to report the episode in counties that had received more African Americans in previous years. Results are driven by white newspapers, and the higher reporting lasts for more than one month after a lynching. These patterns resonate with the idea that the Great Migration increased the salience of racial oppression prevailing in the South, thereby raising support for civil rights among at least some segments of the white electorate.

Our findings may seem at odds with the literature on white flight and the detrimental consequences that the latter had on Black migrants and their offspring in the long run (Boustan, 2010; Derenoncourt, 2018). ${ }^{5}$ However, Black political empowerment and white flight are not necessarily in contrast with each other. For one, there is extensive evidence that the Great Migration did economically benefit Black migrants (Baran et al., 2020; Boustan, 2016; Collins and Wanamaker, 2014). In addition, whites may have supported civil rights, while at the same time moving from central cities to the suburbs. From the lens of a Tiebout (1956) framework, whites may have expressed their preferences regarding neighborhood-level diversity and school mixing with their feet, while using the ballot box to express their more abstract ideological preferences about racial equality. Supporting this conjecture, we show that whites living in counties with higher 1940 residential segregation were more likely to both support civil rights and create more school districts, potentially to separate themselves from incoming Black migrants. $^{6}$

In the second part of the paper, we turn to the ideology and behavior on racial issues of legislators representing non-southern congressional districts (CDs). Similar to Autor

\footnotetext{
${ }^{5}$ The Great Migration also increased racial disparities in incarceration rates (Eriksson, 2019; Muller, 2012), and worsened public finances in northern cities (Tabellini, 2018). See Collins (2021) for a thorough review.

${ }^{6}$ Consistent with polarization within the white electorate, historical survey data also suggest that the Great Migration increased support for racial equality among white Democrats, but reduced it among Republicans.
} 
et al. (2020), we construct a cross-walk that matches counties to CDs, and develop a procedure that assigns CD boundaries, which changed over time due to redistricting, to the geography of a baseline, the $78^{\text {th }}$, Congress. We measure legislators' ideology on race-related issues using the scores from Bateman et al. (2017), which are based on past voting behavior on civil rights bills, and take more negative values for more liberal ideology.

We find that, over time, CDs that received more African Americans were represented by legislators with a more liberal ideology on racial issues who were also more likely to sign discharge petitions aimed at promoting civil rights bills (Pearson and Schickler, 2009; Schickler, 2016). These average effects, however, mask substantial heterogeneity, as legislators of either party became increasingly polarized on racial issues.

Our results are related to the literature on the civil rights movement. Several papers have studied the consequences of the Civil Rights and the Voting Rights Acts (Aneja and Avenancio-Leon, 2019; Bernini et al., 2018; Cascio et al., 2010; Cascio and Washington, 2014; Reber, 2011), while many others, building on Carmines and Stimson (1989), have investigated the causes of the southern "dealignment" (Besley et al., 2010; Kousser, 2010; Kuziemko and Washington, 2018; Trende, 2012; Wright, 2013). We contribute to this literature by examining one of the causes of the civil rights movement, and showing that the Great Migration likely influenced the latter. Our findings are also consistent with and complement Schickler (2016) and Grant (2020) who, respectively, argue that the incorporation of African Americans into the Democratic coalition after the New Deal and the rising pivotal role of Black voters at the national level due to the Great Migration were important mechanisms behind party realignment in American politics.

We also complement the growing literature on the political effects of migration and the broader literature on inter-group relations (Alesina and Tabellini, 2020). Several papers find that immigration and a larger size of the minority group can lead to backlash among natives or majority members (Arzheimer, 2009; Enos, 2016; Dustmann et al., 2019; Tabellini, 2020). We instead show that, under certain conditions, inter-group contact can favor the formation of cross-race social or political coalitions, raising demand for racial equality also among members of the majority group. ${ }^{7}$ Several factors can explain the difference between our findings and those in the existing

\footnotetext{
${ }^{7}$ Our findings are consistent with those in Lowe (2021), Rao (2019), and Steinmayr (2020) from India and Austria respectively. We complement them by providing evidence from the US and in an instance where group boundaries are defined by race rather than by caste, income, or refugee status.
} 
literature. First, as the evidence from newspapers' reporting of southern Black lynchings suggests, Black in-migration likely increased whites' awareness of the conditions prevailing in the South (Myrdal, 1944). Second, the civil rights legislation was, by and large, about the South, and northern whites would have been only indirectly - if at all - affected, at least before 1965. Third, labor unions had incentives to incorporate African Americans in their rank and files (Adams, 1966; Bailer, 1944; Schickler, 2016), forging a shared working class identity and pursuing common goals - conditions that contributed to positive inter-group contact (Allport, 1954). Finally, our average effects mask substantial heterogeneity, indicating that the Great Migration did not improve racial attitudes among all northern whites, and led to higher polarization both among voters and among legislators.

Our work also speaks to the literature on the relationship between voters' demand and politicians' behavior (Caughey and Warshaw, 2018; Jones and Walsh, 2018; Kroth et al., 2016; Lott and Kenny, 1999; Mian et al., 2010; Miller, 2008). Closest to our paper, Cascio and Washington (2014) document that the Voting Rights Act (VRA) shifted the distribution of local spending across southern counties towards Black Americans' preferences, once the latter became eligible to vote. We expand on their findings by focusing on the US North rather than the South, and by analyzing one of the potential causes, rather than consequences, of the VRA - i.e., the response of northern politicians to the change in the characteristics, and thus in the demands, of their constituency due to Black in-migration.

Finally, we complement the vast literature on the Great Migration (Collins, 2021). Although several papers in economics have studied the effects of the Great Migration on whites' residential decisions, intergenerational mobility, immigrant assimilation, and public finance (Boustan, 2010; Derenoncourt, 2018; Fouka et al., 2021; Shertzer and Walsh, 2019; Tabellini, 2018), little evidence exists on its political effects.

\section{Historical Background}

\subsection{The Great Migration}

Between 1940 and 1970, more than 4 million African Americans left the US South for northern and western destinations. This unprecedented migration episode is usually referred to as the Second Great Migration. From 1915 to 1930, the First Great Migration brought to the North 1.5 million Black Americans. However, the Second 
Great Migration - from now onwards the Great Migration - was substantially larger in magnitude and had more profound implications for American politics and race relations (Boustan, 2016). Most Black migrants moved to urban centers in the Northeast and mid-West, but the Great Migration was a geographically widespread phenomenon, which affected also the West and less urbanized areas outside the South (Figure 1). ${ }^{8}$

Black migrants were pulled to the North and West by economic opportunities and pushed out of the South by racial oppression, political disenfranchisement, and poor working conditions (Boustan, 2016). On the one hand, the outbreak of WWII increased demand for labor in northern and western factories, raising the potential gains from migration. Even after the WWII-related labor demand shock was over, higher expectations of upward social and economic mobility kept attracting African Americans to the North at least until the late 1960s. On the other hand, widespread violence and disenfranchisement, together with a separate and unequal school system, provided strong incentives for Black Americans to leave the South (Feigenbaum et al., 2020; Margo, 1991). Moreover, the mechanization of agricultural harvest in the 1940s and 1950s reduced demand for labor in the already depressed southern agricultural sector, further increasing the pool of prospective migrants (Grove and Heinicke, 2003; Whatley, 1985).

Out-migration from the South was strongest during the 1940s, with a Black emigration rate of almost 15\%, but remained high until the late 1960s (Figure A.1). As a consequence of this migration episode, during which the US South lost $40 \%$ of its 1940 Black population, the racial profile of the United States changed dramatically. While only $25 \%$ of African Americans were living outside the South in 1940, this figure had increased to more than $50 \%$ by 1970 . On average, the Black share of the population in northern and western cities moved from less than $4 \%$ to more than $15 \%$ in just three decades. These numbers were an order of magnitude higher for main hubs like Chicago, Detroit, or St. Louis, where the Black share moved from 8, 9, and 11\% to 32, 43, and $41 \%$ respectively (Gibson and Jung, 2005). ${ }^{9}$

\footnotetext{
${ }^{8}$ When defining the US South, we follow the Census classification but, as in Boustan (2010), we exclude Maryland and Delaware - two states that received net Black inflows during the Great Migration (Table A.1). As Figure 1 makes clear, most California's counties are missing from our sample due to the lack of data on Congressional elections at the county level for this historical period. We return to this point in Section 3 and in Appendix D.

${ }^{9}$ In rural counties, the Black share remained substantially lower and rarely exceeded 2 or $3 \%$.
} 


\subsection{Black Migrants and Northern Politics}

The demographic change induced by the Great Migration had the potential to alter the political equilibrium, especially in industrial and urban centers. In the US South, Black Americans faced de jure disenfranchisement through the use of literacy tests, poll taxes, and grandfather clauses (Cascio and Washington, 2014; Lawson, 1976). On the contrary, they could, and in fact did, vote in the North (Moon, 1948). The literature on social movements has documented that the enfranchisement of Black migrants increased both the organizational capacity of the civil rights movement and pressure on local politicians (McAdam, 1982). During the First Great Migration, both Democrats and Republicans had tried to include African Americans in their voting bloc. However, since the New Deal, the Democratic Party had emerged as the party better equipped to address the demands of Black Americans outside the US South (Caughey et al., 2020; Schickler, 2016).

Figure A.2 plots the share of northern Democrats (blue bars) and Republicans (red bars) voting in favor of civil rights bills between Congresses 78 and 88 (see Table A.2 for the detailed list of bills). Both in the 1940s and in the 1950s, Democrats in the North were more likely to support civil rights bills. ${ }^{10}$ Using data from Pearson and Schickler (2009), Figure A.4 confirms these patterns by focusing on signatures on pro-civil rights discharge petitions - another, more direct, measure of legislators' commitment to racial equality (Schickler, 2016). ${ }^{11}$ Non-southern Democratic Congress members were at least 30 percentage points more likely than their Republican counterparts to sign a discharge petition to promote civil rights legislation between Congress 78 and Congress 82 . The gap rose to more than 50 percentage points in the following decade (Table A.3).

Northern Black residents were significantly more likely to support the Democratic Party. Existing evidence indicates that at least $70 \%$ of registered Black voters outside the South were voting Democratic already in 1936 - a share that gradually increased over time (Bositis, 2012). Democrats also benefited from the behavior of labor unions - the CIO in particular - that, since the late 1930s, started to actively incorporate African Americans in their ranks. ${ }^{12}$ This represented a shift away from the segrega-

\footnotetext{
${ }^{10}$ Figure A.3 documents that the pattern is reversed once the US South is included.

${ }^{11}$ At a time when southern Democrats could block any proposed civil rights-related bill even before it reached the floor of the House, discharge petitions were filed by northern legislators to circumvent congressional committees, and move bills to the floor for a vote (Beth et al., 2003). For more details see Section 3 and Appendix C.

${ }^{12}$ Using data from Gallup, Farber et al. (2021) document that, while non-southern white men were significantly more likely than Black men to be union members in 1940, this pattern had been reversed by 1960 .
} 
tionist practices prevailing before 1940, and was not true for all unions. ${ }^{13}$ Abundant anecdotal evidence exists that labor unions openly endorsed civil rights and backed African Americans in their fight for racial equality (Adams, 1966; Bailer, 1944). For instance, CIO leader J. Brophy declared in 1944 that "behind every lynching is the figure of the labor exploiter...who would deny labor its fundamental rights". Similarly, in 1942 Walter Reuther, a highly influential figure in the United Automobile Workers (UAW), declared that "...[racial discrimination] must be put on top of the list with union security and other major union demands" (Zieger, 2000). In line with these statements, evidence from the Congressional Quarterly Almanac shows that, for the 42 cases in which the NAACP took a clear position on a proposed piece of legislation between 1946 and 1955, the CIO openly took the very same position in 38 cases, and never took a position conflicting with that of the NAACP (Schickler, 2016). As a result, a class-based coalition, pushing for both racial and economic liberalism, emerged. This gave additional leverage to Black activists and organizations such as the NAACP and the CORE to exert pressure on northern Democrats to pursue the civil rights agenda.

\section{Data}

This section briefly describes the key outcomes of the paper. Appendix B presents the time-invariant cross-walk used to map counties to CDs, fixing CD boundaries to the baseline Congress of 1944 (Congress 78). Appendix C provides a more detailed description of all data sources.

Demand for civil rights. We measure demand for civil rights using two main outcomes: the Democratic vote share in Congressional elections, and the frequency of pro-civil rights demonstrations. We complement these with data on the local presence of NAACP chapters, on whites' attitudes obtained from the American National Election Studies (ANES) and Gallup public opinion polls, and on references to lynchings against Black Americans occurring in the US South reported in non-southern local newspapers. Our focus on the Democratic vote share in Congressional elections is motivated by the fact that, by 1940, Democrats had become the main supporters of racial equality outside the US South (see Section 2.2) and that such support was more likely to emerge in Congressional rather than Presidential elections (Caughey et al.,

\footnotetext{
${ }^{13}$ For instance, the American Federation of Labor (AFL) remained openly segregationist.
} 
2020; Schickler, 2016). ${ }^{14}$ To more directly capture demand for racial equality, we use the dataset assembled by Gregory and Hermida (2019) combining a variety of sources on the number of non-violent demonstrations organized between 1942 and 1970 by the CORE - a major inter-racial civil rights organizations that coordinated sit-ins and similar forms of civil disobedience.

Supply of civil rights. To measure legislators' support for civil rights we use the ideology scores from Bateman et al. (2017) and signatures on discharge petitions to promote civil rights legislation from Pearson and Schickler (2009). Ideology scores are a function of legislators' past voting behavior on race-related bills and, as the commonly used DW Nominate scores (Poole and Rosenthal, 1985), take more negative (resp. positive) values for more liberal (resp. conservative) positions. Discharge petitions represented an effective tool at the disposal of non-southern legislators for overcoming the gatekeeping behavior of southern Democrats. The latter - due to the seniority system prevailing at the time - frequently controlled committees that could block bills aimed at increasing racial equality before they reached the floor of the House (Schickler, 2016)..$^{15}$

Our final dataset is composed of the 1,263 non-southern counties (and, for the analysis on legislators, $285 \mathrm{CDs}$ ) for which all outcomes are available for all Census years. Since data on Congressional elections are not available for all years in several counties in California, our baseline analysis excludes most of the state (Figures 1 and A.5). Reassuringly, Appendix D shows that all results are unchanged when considering the unbalanced sample, which includes California.

Table 1 presents summary statistics for our main variables, reporting 1940 levels in Panel A and their (decadal) changes in Panel B. The Black share in the average county in our sample was around 3.5\% in 1940, and increased to almost 9\% in 1970 (not shown). These average values, however, mask substantial heterogeneity. Figure A.5 plots the 1940 Black share for the counties in our sample, and shows that, in 1940, Black migrants living outside the South were concentrated in the urban centers of the Northeast and the Midwest, in border states, and in the Southwest. In 1940, the Black share was already as high as $8 \%$ in Cook County (IL), and rose to $21.5 \%$ by 1970 . Similarly, the Black share in Philadelphia County (PA) increased from around $12 \%$ in

\footnotetext{
${ }^{14}$ Data on Congressional elections come from Clubb et al. (1990). See Appendix C for more details.

${ }^{15}$ If a proposed bill remained stuck in the Rules Committee (resp. a legislative committee) for more than seven (resp. twenty) days, a discharge petition could be filed and, were it to receive at least 218 signatures, the bill could move to the floor of the House (Beth et al., 2003).
} 
1940 to almost $35 \%$ in 1970, whereas that in Clark County (NV) rose from less than $3 \%$ to about $10 \%$ during the same period (Figure A.6).

The 1940 Democratic vote share in Congressional elections was on average 46.5\%; in the $78^{\text {th }}$ Congress, civil rights scores were on average negative $(-0.87)$, indicating that northern legislators were relatively liberal on racial issues already by 1940 . The average decadal change in ideology scores was very close to zero, even though this masks important differences both between parties and between Congress periods (Bateman et al., 2017; Schickler, 2016). Signatures on discharge petitions were significantly more common in the $78^{\text {th }}-82^{\text {nd }}$ than in the $83^{\text {rd }}-88^{\text {th }}$ Congress period (Table A.4), and their subjects changed markedly over time. While the poll tax and anti-discrimination employment (FECP) legislation were the most common topics during the 1940s, 5 of the 8 discharge petitions filed between the $83^{\text {rd }}$ and the $88^{\text {th }}$ Congress concerned the CRA. ${ }^{16}$

\section{Empirical Strategy}

\subsection{Estimating Equation}

Our empirical analysis is divided in two parts. First, we estimate the effects of the Great Migration on demand for civil rights legislation; second, we analyze the response of northern legislators to changes in the composition and preferences of their electorate. To be clear: we do not attempt to isolate the impact of changes in voters' demand, due to Black inflows, on legislators' behavior. In fact, both parties likely re-optimized their platforms strategically because of the Great Migration, in turn influencing the actions of voters - both Black and white. Our goal is instead to estimate the "reduced form" effect of Black in-migration on voters' demand and politicians' supply without taking a stance on how the two influenced each other.

Starting from the demand side and stacking the data for the three decades between 1940 and 1970, we estimate

$$
\Delta y_{c \tau}=\delta_{s \tau}+\beta \Delta B l_{c \tau}+\gamma X_{c \tau}+u_{c \tau}
$$

where $\Delta y_{c \tau}$ is the change in the outcome of interest in county $c$ during decade $\tau$. When focusing on electoral outcomes, $y_{c \tau}$ refers to the Democratic vote share and turnout in

\footnotetext{
${ }^{16}$ See Appendix $\mathrm{C}$ for the list of discharge petitions on civil rights by topic and Congress (Table C.1).
} 
Congressional elections. When considering grassroots activism, $y_{c \tau}$ is the probability of pro-civil rights demonstrations organized by the CORE and the presence of local NAACP chapters. In order to identify the effects for the average county, we weigh regressions by 1940 county population, but results are robust to estimating unweighted regressions. Standard errors are clustered at the county level.

The key regressor of interest, $\Delta B l_{c \tau}$, is the change in the Black share in county $c$ during decade $\tau . \delta_{s \tau}$ includes interactions between decade and state dummies, and $X_{c \tau}$ is a vector of interactions between decade dummies and 1940 county characteristics. Our preferred specification includes the 1940 Black share and a dummy equal to one for Democratic incumbency in 1940 Congressional elections. In Appendix D, we add more interactions to probe the robustness of our results. Since equation (1) is taken in stacked first differences and always controls for interactions between period and state dummies, the coefficient of interest, $\beta$, is estimated from changes in the Black share within the same county over time, as compared to other counties in the same state in a given period.

Turning to the supply of civil rights, $c$ no longer refers to the county but, instead, to the CD. ${ }^{17}$ When considering ideology scores, we restrict attention to two - rather than three - periods, so as to end our analysis with the Congress that passed the CRA (Congress 88). Instead, for signatures on discharge petitions, we are forced to estimate equation (1) only for the 78-82 Congress period, when a sufficient number of petitions were filed both at the beginning and at the end of the decade.

\subsection{Instrument for Changes in Black Population}

The key empirical challenge for our analysis is that Black migrants might have sorted in places that were already undergoing economic and political changes. To overcome these and similar concerns, we predict Black inflows in northern area $c$ during decade $\tau$ using a version of the shift-share instrument commonly adopted in the migration literature (Boustan, 2010; Card, 2001). The instrument predicts the change in the Black population in county $c$ during decade $\tau$ by interacting the share of Black migrants born in southern state $j$ and living in northern county $c$ in 1940 (relative to all Black migrants born in state $j$ living outside that state in 1940), $s h_{j c}$, with the number of Black migrants who left state $j$ during period $\tau, B l_{j \tau}$ :

\footnotetext{
${ }^{17}$ We construct a time-invariant unit, described in Appendix B, to deal with redistricting. Regressions are weighed by CD population, and standard errors are clustered at the CD level.
} 


$$
Z_{c \tau}=\sum_{j \in \text { South }} s h_{j c} B l_{j \tau}
$$

Since we are interested in the effects of changes in the Black share, we scale $Z_{c \tau}$ by 1940 county population.

As discussed in Boustan (2010) among others, Black settlements in the North were highly persistent over time. At the turn of the twentieth century, as African Americans started to move northwards, migration patterns were influenced by the newly constructed railroad network. For instance, the presence of the Illinois Central, which connected several Mississippi counties to Chicago and a number of southern railroads to northern hubs in Missouri and Illinois, explains why Black migrants from Mississippi were disproportionately concentrated in Chicago or St. Louis (Grossman, 1991). The stability of Black enclaves was further reinforced by the process of chain migration during the First Great Migration (Collins and Wanamaker, 2015). Figure A.7 plots the share of Black migrants born in Alabama, Mississippi, and Texas living in selected northern counties in 1940, documenting the wide variation in settlement patterns across both destination and origin areas.

\subsubsection{Identifying Assumptions and Instrument Validity}

Several recent papers discuss the conditions for the validity of shift-share designs (Adao et al., 2019; Borusyak et al., 2021; Goldsmith-Pinkham et al., 2020; Jaeger et al., 2018). One way to express the identifying assumption behind the instrument is as follows. Conditional on controls, third factors affecting the trajectories of political conditions after 1940 must not be simultaneously correlated with both: i) the 1940 mix, in terms of southern state of origin, of Black enclaves across non-southern counties, and $i i$ ) emigration rates from different southern states after 1940.

As formalized in Borusyak et al. (2021), a large number of shocks that are orthogonal to changes in outcomes in the destination (in our setting, support for racial equality in non-southern counties) guarantee the validity of the shift-share design. Our instrument combines actual out-migration flows with a (southern) state to (northern) county migration matrix. For these reasons, we cannot immediately invoke the result in Borusyak et al. (2021). However, as described in detail in Appendix D, we verify that our results are unchanged when using versions of the instrument that are likely to meet the conditions in Borusyak et al. (2021). 
First, as in Boustan (2010), we replace actual out-migration from southern states with that estimated by exploiting only conditions across southern counties (and then aggregated up to the state level), such as WWII spending, 1940 cotton acreage, and 1940 employment share in agriculture, manufacturing, and mining. ${ }^{18}$ Second, and similar to Derenoncourt (2018), we develop an alternative version of the shift-share instrument, based on a linked sample of African American migrants between 1910 and 1930 from Abramitzky et al. (2020). This instrument, which is based on a county-tocounty (rather than state-to-county) migration matrix, effectively exploits variation in predicted migration from more than 1,200 southern counties. Since conditions across southern counties are plausibly orthogonal to the evolution of political ideology in northern counties (Derenoncourt, 2018), the identifying assumption is likely to hold in this case (Borusyak et al., 2021). ${ }^{19}$

Push instruments already reduce concerns about spurious correlation with specific shocks hitting northern counties that both affected local conditions and influenced outmigration across southern states over time. We provide two additional pieces of evidence against this possibility. First, we document that the instrument is uncorrelated with either WWII spending or the generosity of New Deal relief programs. Second, similar to Sequeira et al. (2020), we replicate the analysis by separately controlling for a measure of predicted labor demand, constructed by interacting the 1940 industrial county composition with the national growth rate of different industries between 1940 and 1970 .

We also perform a number of additional robustness checks. First, we show that pre-period changes in the outcomes of interest are not correlated with the instrument. Second, we interact period dummies with several 1940 county characteristics (e.g., the Black and the urban share of the population, support for the Democratic Party, and the share of employment in manufacturing) and with time-invariant geographic controls (e.g., distance from the Mason-Dixon line, latitude and longitude, distance from the closest city where the Forty-Eighters settled). ${ }^{20}$

These exercises assuage the concern that the characteristics of counties where Black

\footnotetext{
${ }^{18}$ Predicting out-migration using southern push factors also assuages the potential concern of serial correlation in migration flows from the same location to the same destination (Jaeger et al., 2018) over time.

${ }^{19}$ In Appendix D, we also present standard errors corrected using the procedure from Adao et al. (2019).

${ }^{20}$ Dippel and Heblich (2021) show that the Forty-Eighters - leaders of the failed 1848-1849 German revolution who migrated to the US - had long-lasting and profound effects on support for racial equality. One may thus be worried that distance from cities where the Forty-Eighters settled might be correlated both with enclaves of Black individuals born in southern states that sent more migrants after 1940 and with the evolution of political preferences in the US North and West.
} 
migrants from specific states settled before 1940 may be correlated both with post1940 Black migration and with changes in support for civil rights in northern counties (Goldsmith-Pinkham et al., 2020). In particular, controlling for the interaction between the 1940 Black share and period dummies, as we do in our preferred specification, implies that the instrument only exploits variation in the (southern state) composition of African Americans' enclaves across counties, holding constant the size of their Black populations.

\section{Demand for Civil Rights}

\subsection{Main Results}

\subsubsection{Congressional Elections}

We start by studying the effects of the Great Migration on the Democratic vote share in Congressional elections, which we interpret as a proxy for voters' demand for civil rights. Panel A of Table 2 estimates equation (1) with OLS in columns 1 to 3, and with 2SLS from column 4 onwards. Column 1 only includes state by decade fixed effects, while columns 2 and 3 add interactions between decade dummies and, respectively, the 1940 Black share and an indicator for Democratic incumbency in 1940. In all cases, the point estimate on the change in the Black share is positive and statistically significant.

Turning to 2SLS, Panel C shows that the instrument is strong, and the F-stat for weak instruments is always above conventional levels. In our preferred specification - which includes interactions between period dummies and: $i$ ) state dummies; $i i)$ the 1940 Black share; and iii) an indicator for Democratic incumbency in 1940 - the first stage coefficient implies that one percentage point increase in the predicted Black share raises the actual Black share by 0.75 percentage points (column 6).

2SLS estimates confirm OLS results, but are larger in magnitude, especially for our preferred specification (column 6) and when estimating long difference regressions (column 7). According to our preferred specification, one percentage point increase in the Black share raised the Democratic vote share by 1.88 percentage points, or $4 \%$ relative to the 1940 mean. For large recipient counties such as Cook (IL) or Wayne (MI) county, where the Black share increased by more than 15 percentage points between 1940 and 1970, Black in-migration had the potential to alter the political landscape dramatically. These findings likely reflect a combination of $i$ ) migrants' direct political 
engagement, and $i$ ) changes in the preferences and voting behavior of existing residents. We return to this point in Section 5.3 below, when exploring the mechanisms, but we already note that the 2SLS coefficient in column 6 of Panel A is statistically different from 1 at the $5 \%$ level.

The difference between OLS and 2SLS estimates indicates that Black migrants selected areas where support for the Republican Party was rising faster. This might have happened because these counties were experiencing faster income growth. ${ }^{21}$ Another possibility, not in contrast with the previous one, is that the IV identifies a local average treatment effect (LATE) for counties that received more Black migrants because of family networks and not because of economic conditions. If Black individuals moving to a specific location due to the presence of networks were more politically engaged relative to "economic migrants", this could explain why OLS coefficients are smaller than 2SLS ones.

Panel B of Table 2 estimates the impact of Black in-migration on turnout in Congressional elections. The coefficient from our preferred specification (column 6) is positive and statistically significant, although smaller than for the Democratic vote share. As for the Democratic vote share, OLS coefficients are smaller than 2SLS ones - in this case even negative. The positive effect on turnout is in line with qualitative evidence that Black migrants were quickly incorporated in the political life of northern and western counties (Moon, 1948; Schickler, 2016).

In Appendix E.1.1, we examine how results vary across decades (Table E.1), showing that the effects of the Great Migration were stronger in the 1940s and in the 1960s, and were, instead, muted in the 1950s. ${ }^{22}$ Appendix E.1.1 also verifies that Black inflows had a positive, but smaller, effect on the Democratic vote share in Presidential elections. This is consistent with Schickler (2016), who documents that support for racial equality was stronger within the local fringes of the Democratic Party.

\subsubsection{Pro-Civil Rights Demonstrations and NAACP Chapters}

In Table 3, we turn to the frequency of non-violent demonstrations organized by CORE in support of civil rights. The structure of the table mirrors that of Table 2, reporting

\footnotetext{
${ }^{21}$ Consistent with this idea, in our sample there is a negative and statistically significant relationship between the change in the Democratic vote share and a number of proxies for economic growth, such as population growth, population density, and industrial expansion.

${ }^{22}$ One interpretation for these patterns is that the economic downturns of the 1950s temporarily halted the progress of race relations, cooling off whites' support for racial equality (Sugrue, 2014).
} 
OLS and 2SLS estimates in columns 1 to 3 and 4 to 7 respectively, and presenting first stage coefficients in Panel B. For brevity, we focus on our 2SLS preferred specification (column 6).

Black in-migration had a strong, positive effect on the probability of CORE demonstrations. One percentage point increase in the Black share led to a 5.7 percentage point increase in the likelihood of protests. CORE was created in 1942, and the frequency of events in our sample of counties between 1942 and 1944 (included) was 0.09. Our estimates thus imply that one percentage point increase in the Black share raised CORE demonstrations by more than $60 \%$ relative to their pre-1945 values. Another way to gauge the magnitude of these estimates is to consider that the average change in the probability of CORE-led protests in our sample is 0.138 . Hence, one percentage point increase in the Black share explains more than one third of the change in pro-civil rights demonstrations across non-southern counties between 1940 and 1970. We refer the interested reader to Appendix E.1.2, where we use information on the cause and the target of the protest to analyze the heterogeneity of results across type of events (Figures E.1-E.2 and Table E.2).

In Table 4, we focus on the 1940-1960 change in the probability that a county had a NAACP chapter in place. ${ }^{23}$ In the full sample, there is no statistically significant effect on the presence of NAACP (column 3). However, the impact of Black in-migration becomes positive, statistically significant, and quantitatively relevant for counties that did not have a chapter in 1940 (column 4). ${ }^{24}$ The fact that we do not find any effect for counties that already had a chapter in place in 1940 is not surprising. In these places, Black inflows likely increased the number of members of NAACP chapters something that we are not able to measure in our data. Instead, in counties where the NAACP was not present at baseline, Black in-migration likely created a critical mass of activists that justified the opening of new local chapters.

\footnotetext{
${ }^{23}$ We use this specification because, as noted in Appendix C, data on NAACP chapters are only available for 1940 (or earlier) and 1960.

${ }^{24}$ In column 4, the F-stat falls below conventional levels, suggesting that results should be interpreted with some caution.
} 


\subsection{Robustness Checks}

\subsubsection{Addressing White Flight}

A potential concern with the interpretation of our findings is that Black arrivals induced white residents to move to another county (Boustan, 2010). We provide different pieces of evidence, detailed in Appendix D and briefly summarized here, that our results are not due to white flight. First, we replicate the analysis considering a larger geographic unit, the commuting zone $(\mathrm{CZ})$, which contained both central cities and their suburbs (Tables D.1 and D.2). Any potential white flight induced by Black inflows should thus take place within, and not across, CZs. Second, we replicate the analysis conducted in Boustan (2010), and document that Black in-migration did lead to white departures in central cities, but not in counties in our sample (Tables D.3, D.4, D.5, and D.6). Since the central city-suburb divide does not overlap with county boundaries, the reallocation of whites between cities and suburbs was likely absorbed within counties. Finally, we show that Black inflows were not associated with changes in the composition of white residents and, consistent with Boustan (2009), did not have any impact on whites' labor market outcomes (Tables D.7 and D.8). ${ }^{25}$

\subsubsection{Summary of Additional Robustness Checks}

Appendix D performs additional robustness checks. First, we verify that results remain unchanged when constructing versions of the instrument that only exploit variation in push factors across southern counties (Tables D.9 and D.10), and that rely on a county-to-county migration matrix to construct the initial shares (Table D.11). Second, we show that the instrument is uncorrelated with two potential pull factors: WWII spending and New Deal relief programs (Table D.12), and we replicate the analysis controlling for predicted industrialization, constructed by exploiting the 1940 industrial composition of non-southern counties (Table D.13). Third, we check that there are no pre-trends (Tables D.14 and D.24). Fourth, we interact period dummies with several 1940 or time-invariant county characteristics, such as the urban share, the employment share in manufacturing, the employment to population ratio, county geographic coordinates, distance from the Mason-Dixon line and from the closest city where the Forty-Eighters moved to (Tables D.15 and D.16).

\footnotetext{
${ }^{25}$ Due to data limitation this exercise is conducted at the CZ level, estimating long difference regressions for the 1940-1960 period.
} 
We also verify that results: $i$ ) are robust to considering an unbalanced sample that includes all county-decade observations for which outcomes are available, excluding potential outliers, estimating alternative specifications, and measuring electoral outcomes in different ways (Tables D.17, D.18, D.19, D.20, and D.21); ii) are not driven by the simultaneous inflow of southern whites (Tables D.18 and D.19); and, iii) are robust to clustering standard errors at the $\mathrm{CZ}$ level and to using the procedure suggested in Adao et al. (2019) to adjust standard errors (Tables D.22 and D.23). ${ }^{26}$

\subsection{Mechanisms}

\subsubsection{Black in-Migration and Whites' Attitudes Towards Civil Rights}

Bounds on whites' voting behavior. We begin with a back of the envelope calculation that suggests that not only Black but also white voters' behavior changed in a progressive direction in response to Black in-migration. The coefficient reported in Table 2, column 6, indicates that Black in-migration increased the Democratic vote share by more than one for one. This points to the importance of changes in northern residents' voting patterns. In Figure E.3, we compute how many white Republican voters would need to switch to the Democratic Party under different assumptions on Black turnout and voting preferences, in order to explain away our estimated effect on Democratic vote share. ${ }^{27}$ If Black residents voted for the Democratic Party at a rate of $70 \%$, as estimated by the literature (Bositis, 2012), and if we assume a similar behavior for Black migrants, our 2SLS coefficient implies around three white voters switching from the Republican to the Democratic party for every ten incoming Black migrants.

Because it relies on assumptions about Black voting behavior, this exercise is suggestive. We thus only report it in detail in Appendix E.2.1. Yet, it shows that, under reasonable assumptions, Black migrants alone are not sufficient to explain the increase in the Democratic vote share estimated above, and that at least some northern residents - both Black and white - would have to start voting for the Democrats.

Additional evidence from CORE demonstrations. To corroborate the idea that Black in-migration increased support for racial equality among at least some white voters, we exploit the fact that, for a subset of pro-civil rights demonstrations, we can identify the race of participants. In column 7 of Table 3, we estimate our preferred

\footnotetext{
${ }^{26}$ Appendix D also performs additional robustness checks on CD results presented in Section 6.

${ }^{27}$ When performing this exercise, we fix turnout, assuming that the inflow of Black migrants can change the preferences of existing voters but does not alter the number of northern residents (of either race) voting.
} 
specification using as dependent variable the change in the probability of CORE demonstrations with both Black and white participants. This represents a (very conservative) lower-bound for the probability that whites joined pro-civil rights demonstrations, since participants' race was reported only for approximately $40 \%$ of CORE events, and we define a protest as having white participants only when their presence was explicitly reported. The point estimate is smaller than that of the baseline specification (column $6)$, but remains positive and statistically significant at the $5 \%$ level.

Evidence from historical survey data. We complement the previous results with historical survey data from the ANES. We are unable to conduct a county-level analysis because of the very limited number of counties and of respondents per county included in the survey (Appendix C). We instead perform this exercise at the state level. Since questions on racial views are available only from the end of the 1950s, we estimate cross-sectional regressions, correlating whites' racial attitudes and political preferences in surveys conducted in years close to the CRA with the (instrumented) 1940-1960 change in the Black share in their state of residence. ${ }^{28}$ We include survey year and Census region fixed effects and a set of 1940 state (manufacturing share, urban share, share of unionized workers, Black share, and an indicator for Democratic incumbency in Congressional elections) and individual (gender, marital status, and fixed effects for both age and education) controls. ${ }^{29}$ We restrict attention to white respondents living in non-southern states. To deal with the potential concern that white respondents may have moved across states because of Black in-migration, we further restrict attention to whites living in their state of birth.

In Table 5, the dependent variable is a dummy equal to 1 if support for civil rights was considered by respondents as one of the most important problems for the country in 1960 and 1964. In the same survey years, respondents were also asked whether they opposed school and housing or working space integration. Combining these questions, columns 1 to 3 verify that considering civil rights as one of the most important problems is negatively correlated with opposition to racial integration. We thus interpret the dependent variable in Table 5 as a proxy of support for racial equality. Columns

\footnotetext{
${ }^{28}$ Although some of these questions were asked also after 1964, we refrain from using any post-CRA survey dataset because of the potential direct effect of the bill on whites' racial attitudes (Kuziemko and Washington, 2018; Wheaton, 2020).

${ }^{29}$ Since party identification and union membership may be endogenous to Black inflows, we do not include them in our baseline specification. Adding these controls does not change any of our results. Results are also robust to including further 1940 state level controls such as the immigrant share, the share of unskilled workers, and other socioeconomic or political variables.
} 
4 and 5 turn to the relationship between the 1940-1960 change in the Black share and the dummy for civil rights being the most important issue, using OLS and 2SLS respectively.

2SLS estimates indicate that white respondents living in states that received more Black migrants between 1940 and 1960 were significantly more likely to consider civil rights one of the country's most important problems. The coefficient reported in column 5 implies that one percentage point increase in the Black share between 1940 and 1960 is associated with a 3.4 percentage points (or, 30\%) higher probability of reporting civil rights as the most important problem in the two ANES surveys asked before the CRA.

We also consider whites' political preferences. Focusing on survey waves between 1956 and 1964 and estimating 2SLS regressions, Table A.5 documents that white respondents living in states that received more Black migrants between 1940 and 1960 were significantly more likely to vote for the Democratic Party. This relationship becomes an order of magnitude stronger when restricting attention to 1964 (columns 2 and 4). The fact that coefficients are higher for 1964 is consistent with the civil rights issue featuring more prominently during the year that led to the passage of the CRA. ${ }^{30}$

Appendix E.2.3 explores the heterogeneity of racial attitudes across white respondents. It shows that the positive relationship between whites' attitudes towards racial equality and Black in-migration was stronger among union members (Figure E.4). It also reveals that self-identified Democrats were more supportive of civil rights in states that received more African Americans between 1940 and 1960, while the opposite was true for self-identified Republicans. Given the potential endogeneity of partisanship, these patterns are merely suggestive. However, they indicate that the Great Migration might have increased polarization on racial issues within the northern electorate. ${ }^{31}$

\subsubsection{Unpacking the Channels Behind Whites' Support for Civil Rights}

At least two mechanisms can explain the positive effects of Black in-migration on support for racial equality among (at least some) northern whites. First, progressive Democrats and labor unions may have made civil rights part of their agenda in order to attract Black migrants, forging a class-based cross-race coalition between white and Black members of the working class (Adams, 1966; Sugrue, 2008).

\footnotetext{
${ }^{30}$ Appendix E.2.2 verifies that similar patterns hold when using data from Gallup (Table E.3).

${ }^{31}$ In Table E.5 we also show that the change in the Black share was positively associated with feelings towards Democrats, African Americans, and the NAACP among white respondents.
} 
Second, as envisioned by Myrdal (1944), exposure to Black migrants might have increased whites' awareness of the brutal conditions prevailing in the South, in turn fostering demand for more racial equality. Inter-group contact might have also reduced negative stereotypes and prejudice held by whites, changing their attitudes towards Black Americans (Allport, 1954; Schindler and Westcott, 2020).

Economic and social factors may have interacted, reinforcing each other. For instance, frequent contacts in an environment where Black and white workers had common goals and where they shared a common, class-based, identity may have reduced some of the barriers that traditionally inhibited the formation of a racially diverse coalition. ${ }^{32}$

Political and economic forces. As discussed in Section 2.2, starting in the late 1930s, some of the most important labor unions, such as the CIO, became a crucial ally to African Americans' struggle for equality. Often, unions coordinated with grassroots movements such as the NAACP, jointly pushing for civil rights and progressive economic policy (Schickler, 2016). To test the role of the labor movement, we split counties above and below different proxies for the presence and strength of organized labor, or for its incentives to incorporate African Americans. We report results in Figure 2 and Table A.6, always defining the variables so that higher values refer to stronger presence of, or incentives for, unions to support the civil rights movement.

The surge in civil rights protests was concentrated in counties with a higher share of white workers in manufacturing - the sector where unions were most widespread (Bailer, 1944; Farber et al., 2021). In line with these results, the effects of the Great Migration were stronger, although not statistically different, in counties belonging to states where CIO membership rates were higher. ${ }^{33}$ Pro-civil rights protests were also more frequent where political competition - defined as one minus the absolute value of the margin of victory in 1940 Congressional elections - was higher. This finding is consistent with labor unions (and the Democratic Party) having stronger incentives to coordinate events where the Black vote was more valuable. Precisely in these areas, a better organized political machine could have made a difference in attracting and mobilizing pivotal, Black and white, voters (McAdam, 1982; Pons, 2018).

Labor unions, and white workers more generally, should have supported racial equal-

\footnotetext{
${ }^{32}$ Using recent data, Frymer and Grumbach (2020) find that white union members hold more liberal attitudes towards minorities in the US.

${ }^{33}$ CIO membership rates are not available at the county level in a systematic way. We thus rely on 1939 state-level CIO membership from Troy (1957).
} 
ity more when labor markets were tighter. Indeed, inter-group contact is more likely to lead to cooperation when it happens in contexts with no competition over scarce resources (Allport, 1954; Blalock, 1967). ${ }^{34}$ Consistent with this idea, Black in-migration led to more demonstrations only where predicted labor demand was stronger. Instead, when predicted labor demand was low, Black inflows significantly reduced the probability of pro-civil rights demonstrations. ${ }^{35}$ These findings are in line with anecdotal accounts noting that backlash was more likely to emerge during economic downturns (Bailer, 1943; Sugrue, 2014). They are also in line with the electoral results discussed in Appendix E.1.1 (Table E.1), which document that the Great Migration had no effect on the Democratic vote share in the 1950s - a decade characterized by slack labor markets and economic recession.

Social forces. It is possible that Black in-migration increased the salience of brutal conditions and racial violence prevailing in the US South (Myrdal, 1944), leading to greater sensitization of northern whites with liberal tendencies. If that was true, one might expect attitudinal shifts to be more pronounced in counties that were already more socially progressive. To test this idea, we split the sample above and below the median of different proxies for progressive attitudes in the local electorate. We report results in Figure 3, rescaling the variables so that higher values refer to socially more progressive counties.

First, we consider the discrimination index constructed in Qian and Tabellini (2020) using historical data from a variety of sources, such as local presence of the KKK and the lynching of Black Americans up to 1939. Results are an order of magnitude larger in counties with lower historical discrimination. The same pattern, though less pronounced, is evident when splitting counties as belonging to states with (blue bars) and without (orange bars) miscegenation laws (Dahis et al., 2020). Second, pro-civil rights demonstrations increased more in counties that were closer to one of the cities where the Forty-Eighters originally settled. As shown in Dippel and Heblich (2021), the presence of the Forty-Eighters was associated with stronger support for racial equality; hence, whites in these places may have been more responsive to news about racial oppression in the South. ${ }^{36}$

\footnotetext{
${ }^{34}$ Several papers document that anti-minority sentiments are more likely to arise during times of hardship (Grosfeld et al., 2020; Oster, 2004; Voigtländer and Voth, 2012).

${ }^{35}$ We predict labor demand using a Bartik-style approach, interacting 1940 industry shares at the county level with national growth rates of each industry in each subsequent decade.

${ }^{36}$ In a few instances, as documented in Table A.6, the F-stat falls below conventional levels, suggesting that results should be interpreted with caution. This problem is particularly pronounced when focusing on counties
} 
Evidence on information transmission. To more directly test Myrdal's "information hypothesis", we obtained the list of (known) lynchings against African Americans between 1940 and 1964 in the US South, compiled from the Monroe Works Today project. ${ }^{37}$ Then, we searched for mentions of such episodes in any non-southern newspaper that we could locate on the website Newspapers.com. To identify a lynching, we search for the joint appearance in the same page of the name and surname of the victim and the place where the lynching occurred. We restrict attention to a window of 4 weeks before and 26 weeks after each episode, and focus on the subsample of 492 counties for which newspaper data is available. ${ }^{38}$ We could locate a total of 1,041 newspapers, only 5 of which explicitly targeted an African American public. In what follows, we consider all newspapers, but results are unchanged when excluding from our sample the 5 African American ones.

We organize the data at the (northern) county-week-episode level, defining as "week 0 " the week in which the lynching occurred (in a southern state). We create an indicator variable if, in a given week, at least one mention of the lynching was found in a county's local newspapers. Focusing on weeks 0 to 26, we regress this indicator against the instrumented 1940-1960 change in the Black share in the county. Since the regressor of interest is defined at the county level, we cannot include county fixed effects. However, we include state, episode, and week fixed effects. ${ }^{39}$ Results from this exercise are reported in Table 6 .

Column 1 considers any lynching that occurred between 1940 and 1964. It shows that, in the weeks following the lynching of a southern Black individual, local newspapers of northern counties were more likely to report the episode in areas that had received more African Americans between 1940 and 1964. Column 2 runs a placebo exercise, restricting attention to lynchings that occurred between 1940 and 1944. The coefficient is no longer statistically significant, and smaller in size. This indicates that

\footnotetext{
further from the cities of the Forty-Eighters. Reassuringly, however, the pattern depicted in Figures 2 and 3 is consistent across proxies for political and social forces.

${ }^{37}$ See also https://plaintalkhistory.com/monroeandflorencework/explore/map2-credits.html.

${ }^{38}$ Table A.7 compares the characteristics of the full sample and the counties in the "newspapers' sample". Not surprisingly, counties in the newspapers' sample had a higher total population, a higher Black share, and were more likely to be urban in 1940. They also experienced a slightly larger increase in their (actual and predicted) Black population share. However, reassuringly, the Democratic vote share and turnout - both their 1940 levels and their change - are remarkably similar between the two sets of counties. Table A.8 verifies that our main results are unchanged when focusing on the sample of counties for which local newspapers could be located.

${ }^{39}$ As in the main analysis, regressions are weighed by 1940 county population, and standard errors are clustered at the county level.
} 
Black in-migration, and not other county-specific characteristics, increased the probability that a southern lynching was reported in a northern newspaper. Consistent with an information transmission mechanism driven by migration, columns 3 to 5 show that the coefficient on the change in the Black share becomes larger as we focus on lynchings that happened in later years.

Figure 4 explores the dynamics behind the patterns just described, zooming in on the 12 weeks around the event -4 weeks before and 8 weeks afterwards. Reassuringly, there is no relationship between the mention of a lynching and the change in the Black share in the weeks before the event. The effect of Black in-migration jumps on the week of the lynching, and then gradually fades away, persisting for at least one month after the event.

Next, in Table 7, we expand the window to include also the 4 weeks before the lynching, and interact the change in the Black share with an indicator equal to one for all weeks after the lynching. We control for a full battery of county, episode, and week by state fixed effects. ${ }^{40}$ Panel A focuses on the 1940-1960 change in the Black share. In line with our previous results, the interaction between the post-event dummy and the change in the Black share is positive and statistically significant when considering years after 1945 (column 3), and this relationship becomes quantitatively larger as we restrict attention to episodes that occurred later (columns 4 to 6). Again, when considering lynchings that occurred between 1940 and 1944, the coefficient is quantitatively small and not statistically significant. Panel B confirms results of Panel A focusing on the 1940-1950 (resp. 1950-1960) change in the Black share in columns 1 to 3 (resp. 4 to $6)$.

Table A.9 compares the effects of Black in-migration when the lynching happened in the southern state that is predicted to have sent more Black Americans into a specific county (columns 1, 3, and 5) relative to the cases in which the lynching took place in another southern state (columns 2, 4, and 6). Results from this exercise are less precise, but suggest stronger effects for lynchings that happened in the largest state of origin of a northern county's Black migrants - especially for the 1940 to 1950 decade.

Taken together, this evidence is consistent with Myrdal's hypothesis: Black inmigration increased the salience of southern discrimination among northern whites. This, in turn, could be a factor behind changed whites' attitudes towards civil rights in Black migrant destinations.

\footnotetext{
${ }^{40}$ County (resp. state by week) fixed effects absorb the main effect of the change in the Black share (resp. the post-event dummy).
} 


\subsubsection{Residential Segregation and Independent Local Governments}

Our findings do not necessarily imply that white residents welcomed Black migrants into their neighborhoods. Both existing work (Boustan, 2010) and our own analysis (Table D.5) indicate that the Great Migration increased within-county racial segregation as whites exerted more effort to avoid sharing public goods with Black Americans (Alesina et al., 1999). Segregation responses might have been compatible with support for civil rights. For one, civil rights legislation was, at least until 1965, a matter that affected mostly the US South. Additionally, increased segregation may itself have helped defuse whites' animosity caused by Black migration into white neighborhoods.

Appendix E.2.4 provides evidence consistent with the latter conjecture (Table E.6). First, Black in-migration increased the frequency of CORE demonstrations only in counties with higher 1940 residential segregation. That is, support for civil rights increased more in counties where inter-group contact in the housing market was lower. Second, Black inflows led to the creation of more school districts in counties where residential segregation was higher. ${ }^{41}$ One interpretation of these patterns, consistent with historical evidence (Sugrue, 2008), is that population sorting within counties and the creation of independent jurisdictions might have reduced potential backlash by allowing whites to live in racially homogeneous communities, where the probability of sharing public goods with Black Americans was low. This, in turn, could have facilitated support for civil rights as a national-level policy issue, and progressive voting motivated by abstract principles of racial equality.

\section{Legislators' Behavior}

\subsection{Ideology Scores and Discharge Petitions}

Ideology scores. We begin the analysis of legislators' behavior by focusing on the ideology scores from Bateman et al. (2017), which take more negative values for more liberal voting behavior on civil rights bills. Columns 1 to 3 in Table 8 present results for the change in agnostic ideology scores, stacking the data for the 78-82 and the 82-88 Congress periods, reporting OLS, 2SLS, and first stage coefficients in Panels A, B, and C respectively. Following Autor et al. (2020) and Bonomi et al. (2020), to deal with mean reversion, in addition to the controls included in our preferred specification

\footnotetext{
${ }^{41}$ These results are in line with those in Alesina et al. (2004).
} 
above, we also add the interaction between period dummies and the baseline ideology score of legislators. The 2SLS coefficient reported in column 1 (Panel B) is negative, but quantitatively small and imprecisely estimated. ${ }^{42}$

When examining results separately by Congress period, a more nuanced picture emerges. Black in-migration had a strong, negative effect on the ideology scores of legislators in the first Congress period (column 2), and a negligible, positive, and not statistically significant effect in the second period (column 3). While the F-stat falls below conventional levels in column 2, suggesting that our estimates should be interpreted with some caution, these findings indicate that legislators' ideology moved to the left between Congress 78 and Congress 82, and did not change significantly afterwards. Results are robust to focusing on the constrained version of the ideology scores (columns 4 to 6 ).

In our baseline specification, we map the 1940-1950 (resp. 1950-1960) Black inmigration to the 78-82 (resp. 82-88) Congress period, so as to both have the longest periods without redistricting and end the analysis with the Congress that passed the CRA. Appendix D.8 verifies that our findings are robust to different timing conventions. It also shows that there are no pre-trends, that results are robust to restricting the sample to CDs that only span the counties from the balanced dataset in Section 5, and that our estimates are not influenced by strategic gerrymandering, possibly induced by Black in-migration (Kaufman et al., 2017).

Signatures on discharge petitions. Due to gatekeeping imposed by southern Democrats, civil rights bills were unlikely to reach the floor of the House, unless northern legislators were willing to undertake non-standard actions. Discharge petitions represent the best example of such non-conventional tools at the disposal of non-southern legislators (Pearson and Schickler, 2009). Since there are not enough discharge petitions filed during the 82-88 Congress period, we focus on the 1940s, when several discharge petitions were filed and signed on the same topics - fair employment legislation (FEPC), the poll tax, and anti-lynching legislation - both at the beginning and at the end of the decade.

Although all three topics featured prominently in the political debate during the 1940s, legislation against discrimination in federal employment likely represented the most salient category, where northern legislators may have tried to signal their (procivil rights) stance the most. First, the salience of the poll tax and anti-lynching

\footnotetext{
${ }^{42}$ As for other tables, the discrepancy between OLS and 2SLS estimates indicates that Black migrants were more likely to move to areas with growing support for Republican, more conservative legislators.
} 
legislation gradually declined relative to that of FEPC during the 1940s. ${ }^{43}$ Second, anti-lynching legislation and, to a lesser extent, the abolition of the poll tax almost exclusively concerned racial relations in the South; conversely, employment protection legislation had a direct impact both in the South and in the North (Sugrue, 2014).

Figure 5 plots the 2SLS point estimate (with 95\% confidence intervals), showing that Black in-migration increased the probability of signing a discharge petition on all topics. Consistent with the previous discussion, the coefficient is larger and more precisely estimated for FEPC legislation than for other categories. ${ }^{44}$

\subsection{Political Polarization}

We examine the possibility that the Great Migration increased political polarization following the approach used in Autor et al. (2020) and Tabellini (2020) for trade and immigration respectively. We define liberal (resp. moderate) Democrats those legislators with an ideology score below (resp. above) the median score for Democrats in Congress 78. Likewise, moderate (resp. conservative) Republicans are defined as Congress members with an ideology score below (resp. above) the median score for Republicans in Congress 78. Table A.11 estimates our baseline stacked first difference specification, using as dependent variable the change in the probability of electing a liberal Democrat, a moderate Democrat, a moderate Republican, and a conservative Republican in columns 1 to 4 respectively.

In Panel A, we pool both Congress periods together. Black in-migration had a positive, but small and not statistically significant, effect on the probability of electing a liberal Democrat. The remaining coefficients are also imprecisely estimated. However, when considering each Congress period in isolation, a different picture stands out. During the 1940s (Panel B), Black in-migration had a strong, positive effect on the probability of electing a liberal Democrat (column 1), while reducing the probability of electing both moderate Democrats (column 2) and conservative Republicans (column 4). If anything, the probability of electing a moderate Republican (column 3) increased with Black inflows, even though results are not statistically significant. Dur-

\footnotetext{
${ }^{43}$ The last discharge petition on either the poll tax or anti-lynching legislation was filed during the $80^{\text {th }}$ Congress, whereas discharge petitions on FEPC were filed also in the early 1950s (Table C.1).

${ }^{44}$ Table A.10 reports the coefficients associated with Figure 5. The change in the probability of signing a petition on FEPC, anti-lynching legislation, and the poll tax is taken over Congresses 81 to 78 , 80 to 77 , and 79 to 77 respectively. Since petitions on the three topics were not always signed in the same Congress year and were not always comparable with each other (Table C.1), we checked the robustness of our results using alternative time windows. Reassuringly, they always remained similar to those presented in Figure 5 .
} 
ing the 1950s (Panel C), in stark contrast with the previous decade, Black in-migration increased the probability of electing a conservative Republican, while reducing that of electing a moderate Republican. The effects of Black in-migration on the probability of electing Democrats with different ideological stances are very small in size and imprecisely estimated.

Figure 6 plots the coefficients reported in Panels B and C of Table A.11. These results suggest that the Great Migration led to changes in legislators' ideology both between and within parties. In the 1940s, Black inflows triggered a general shift towards a more liberal ideology on racial issues within both parties. Moreover, and in line with a between-party adjustment, the probability of electing a (liberal) Democrat increased more than that of electing a (moderate) Republican. In the 1950s, most of the action came from internal changes within the GOP, with legislators moving to the right. Such rightward shift may have been motivated by strategic considerations, as the GOP tried to win the votes of whites who were becoming increasingly concerned about the racial mixing of their neighborhoods (Sugrue, 2014).

Since results during the 1940s are quantitatively larger than those in the 1950 s, on average, legislators' ideology moved to the left. However, when inspecting these dynamics more carefully, polarization becomes evident. The patterns identified here resemble those appearing in the ANES analysis above, which showed that white Democrats and Republicans had, respectively, more positive and more negative views towards civil rights in states receiving more African Americans. Our findings are also consistent with the possibility that local responses to the Great Migration might have been partly influenced by national considerations. Even though Democrats "lost the South" by promoting the civil rights agenda (Kuziemko and Washington, 2018), this strategy might have allowed them to win urban areas of the West and the North. At the same time, the Republican Party might have tried to strengthen its conservative position at the national level, so as to attract dissatisfied southern whites leaving the Democratic Party.

\section{Conclusions}

The Great Migration was the single largest episode of internal migration in American history. Between 1940 and 1970, more than 4 million Black Americans left the US South for northern and western destinations. During this same period, the civil rights 
movement struggled and eventually succeeded to eliminate institutionalized discrimination and formal impediments to Black political participation. In this paper, we study the effects that Black in-migration had on both voters' demand for and legislators' supply of civil rights.

Using a version of the shift-share instrument, we find that Black in-migration increased the Democratic vote share in Congressional elections and raised the frequency of pro-civil rights demonstrations. Our estimates suggest that these effects were at least in part due to the behavior of white voters, who also joined grassroots civil rights activities. Evidence from local newspapers indicates that migration-induced information transmission likely contributed to the change in whites' racial attitudes. Next, we document that legislators representing CDs that received more African Americans became more liberal on racial issues, and more actively supported civil rights legislation. These average effects, however, mask substantial polarization between parties.

Our paper complements the existing literature on the Great Migration, which has, especially in recent times, emphasized the long run, negative impact that this episode had on both racial residential segregation and economic mobility for African Americans. Our findings, instead, paint a more nuanced picture. They indicate that, as predicted by Gunnar Myrdal in 1944, Black in-migration to the US North and West was instrumental for the development of the civil rights movement, and for the concomitant political changes that led to Black political empowerment and progress towards racial equality in the United States.

When contrasted with other works on the political effects of migration, our results raise an intriguing set of questions. Under what conditions can migration and intergroup contact more broadly lead to the formation of cross-group coalitions? When, instead, is backlash from original residents more likely to prevail? In the specific context of the Great Migration and of the civil rights movement, our evidence suggests that cross-race cooperation can emerge when individuals belonging to different groups share similar goals and identities (in this context, class-based), and when information about discrimination becomes available to majority group members who are already more open to diversity. In contexts where inter-group competition over scarce resources cannot be defused (for instance, by increased segregation in the labor market) majority backlash is instead more likely to emerge. 


\section{References}

Abramitzky, R., L. Boustan, and M. Rashid (2020). Census Linking Project: Version 1.0 [dataset]. https://censuslinkingproject.org.

Adams, H. S. (1966). "The Dingell-Lesinski 1964 Primary Race". The Western Political Quarterly 19(4), 688-696.

Adao, R., M. Kolesár, and E. Morales (2019). "Shift-share Designs: Theory and Inference". The Quarterly Journal of Economics 134(4), 1949-2010.

Adler, E. S. (2003). Congressional District Data File, [78]. University of Colorado, Boulder, CO. http://socsci. colorado. edu/ ${ }^{\sim}$ esadler/research. htm.

Alesina, A., R. Baqir, and W. Easterly (1999). "Public Goods and Ethnic Divisions". The Quarterly journal of economics 114(4), 1243-1284.

Alesina, A., R. Baqir, and C. Hoxby (2004). "Political Jurisdictions in Heterogeneous Communities". Journal of political Economy 112(2), 348-396.

Alesina, A. F. and M. Tabellini (2020). "The Political Effects of Immigration: Culture or Economics?". CEPR Discussion Paper No. DP15486.

Allport, G. W. (1954). The Nature of Prejudice. Oxford, England: Addison-Wesley.

Altonji, J. G. and R. M. Blank (1999). "Race and Gender in the Labor Market". Handbook of labor economics 3, 3143-3259.

Aneja, A. and C. F. Avenancio-Leon (2019). "The Effect of Political Power on Labor Market Inequality: Evidence from the 1965 Voting Rights Act". Working paper.

Arzheimer, K. (2009). "Contextual Factors and the Extreme Right Vote in Western Europe, 1980-2002”. American Journal of Political Science 53(2), 259-275.

Autor, D., D. Dorn, G. Hanson, and K. Majlesi (2020). "Importing Political Polarization? The Electoral Consequences of Rising Trade Exposure". American Economic Review 110(10), 3139-83.

Autor, David, H. and D. Dorn (2013). "The Growth of Low-Skill Service Jobs and the Polarization of the US Labor Market". American Economic Review 103(5), 1553-97.

Bailer, L. H. (1943). "The Negro Automobile Worker". Journal of Political Economy $51(5), 415-428$.

Bailer, L. H. (1944). "The Automobile Unions and Negro Labor". Political Science Quarterly 59(4), 548-577. 
Bailey, M. J., C. Cole, M. Henderson, and C. Massey (2020). "How Well Do Automated Linking Methods Perform? Lessons from US Historical Data". Journal of Economic Literature 58(4), 997-1044.

Baran, C., E. Chyn, and B. A. Stuart (2020). "The Great Migration and Educational Opportunity". Working Paper.

Bateman, D. A., J. D. Clinton, and J. S. Lapinski (2017). "A House Divided? Roll Calls, Polarization, and Policy Differences in the US House, 1877-2011". American Journal of Political Science 61 (3), 698-714.

Bayer, P. and K. K. Charles (2018). "Divergent Paths: A New Perspective on Earnings Differences between Black and White Men since 1940". The Quarterly Journal of Economics 133(3), 1459-1501.

Bernini, A., G. Facchini, and C. Testa (2018). "Race, Representation and Local Governments in the US South: The Effect of the Voting Rights Act". Discussion paper No. 12774, CEPR.

Besley, T., T. Persson, and D. M. Sturm (2010). "Political Competition, Policy and Growth: Theory and Evidence from the US". The Review of Economic Studies 77(4), 1329-1352.

Beth, R. S., Government, and F. Division (2003). The Discharge Rule in the House: Principal Features and Uses. Congressional Research Service.

Blalock, H. M. (1967). Toward a Theory of Minority-Group Relations, Volume 325. New York: Wiley.

Bonomi, G., N. Gennaioli, and G. Tabellini (2020). "Identity, Beliefs, and Political Conflict". Working Paper.

Borusyak, K., P. Hull, and X. Jaravel (2021). "Quasi-experimental Shift-share Research Designs". The Review of Economic Studies. Forthcoming.

Bositis, D. A. (2012). Blacks and the 2012 Democratic National Convention. Joint Center for Political and Economic Studies.

Boustan, L. P. (2009). "Competition in the Promised Land: Black Migration and Racial Wage Convergence in the North, 1940-1970". The Journal of Economic History 69(3), 755-782.

Boustan, L. P. (2010). "Was Postwar Suburbanization "White Flight"? Evidence from the Black Migration". The Quarterly Journal of Economics 125, 417-443.

Boustan, L. P. (2016). Competition in the Promised Land: Black Migrants in Northern Cities and Labor Markets. Princeton University Press. 
Boustan, L. P., D. Bunten, and O. Hearey (2018). "Urbanization in the United States, 1800-2000". In Oxford Handbook of American Economic History.

Boustan, L. P., P. V. Fishback, and S. Kantor (2010). "The Effect of Internal Migration on Local Labor Markets: American Cities during the Great Depression". Journal of Labor Economics 28(4), 719-746.

Bowles, G. K., J. D. Tarver, C. L. Beale, and E. S. Lee (1990). Net Migration of the Population by Age, Sex, and Race, 1950-1970 [computer file]. ICPSR ed., Study (8493).

Card, D. (2001). "Immigrant Inflows, Native Outflows, and the Local Labor Market Impacts of Higher Immigration". Journal of Labor Economics 19(1), 22-64.

Carmines, E. G. and J. A. Stimson (1989). Issue Evolution: Race and the Transformation of American Politics. Princeton University Press.

Cascio, E., N. Gordon, E. Lewis, and S. Reber (2010). "Paying for Progress: Conditional Grants and the Desegregation of Southern Schools". The Quarterly Journal of Economics 125(1), 445-482.

Cascio, E. U. and E. Washington (2014). "Valuing the Vote: The Redistribution of Voting Rights and State Funds Following the Voting Rights Act of 1965". The Quarterly Journal of Economics 129(1), 379-433.

Caughey, D., M. C. Dougal, and E. Schickler (2020). "Policy and Performance in the New Deal Realignment: Evidence from Old Data and New Methods". The Journal of Politics 82(2), 494-508.

Caughey, D. and C. Warshaw (2018). "Policy Preferences and Policy Change: Dynamic Responsiveness in the American States, 1936-2014". American Political Science Review 112(2), 249-266.

Chetty, R., N. Hendren, M. R. Jones, and S. R. Porter (2020). "Race and Economic Opportunity in the United States: An Intergenerational Perspective". The Quarterly Journal of Economics 135(2), 711-783.

Clubb, J. M., W. H. Flanigan, and N. H. Zingale (1990). Partisan Realignment: Voters, Parties, and Government in American History. Beverly Hills, CA: SAGE.

Collins, W. J. (2021). "The Great Migration of Black Americans from the US South: A Guide and Interpretation". Explorations in Economic History (101382).

Collins, W. J. and R. A. Margo (2007). "The Economic Aftermath of the 1960s Riots in American Cities: Evidence from Property Values". The Journal of Economic History $67(4), 849-883$. 
Collins, W. J. and M. H. Wanamaker (2014). "Selection and Economic Gains in the Great Migration of African Americans: New Evidence from Linked Census Data". American Economic Journal: Applied Economics 6(1), 220-52.

Collins, W. J. and M. H. Wanamaker (2015). "The Great Migration in Black and White: New Evidence on the Selection and Sorting of Southern Migrants". The Journal of Economic History 75 (4), 947-992.

Dahis, R., E. Nix, and N. Qian (2020). "Choosing Racial Identity in the United States, 1880-1940". Working Paper 26465, NBER.

Derenoncourt, E. (2018). "Can You Move to Opportunity? Evidence from the Great Migration". Working paper.

Dippel, C. and S. Heblich (2021). "Leadership in Social Movements: Evidence from the "Forty-Eighters" in the Civil War". American Economic Review 111(2), 472-505.

Dustmann, C., K. Vasiljeva, and A. P. Damm (2019). "Refugee Migration and Electoral Outcomes". Review of Economic Studies 86(5), 2035-2091.

Engstrom, E. (2013). Partisan Gerrymandering and the Construction of American Democracy. University of Michigan Press.

Enos, R. D. (2016). "What the Demolition of Public Housing Teaches Us about the Impact of Racial Threat on Political Behavior". American Journal of Political Science 60(1), 123-142.

Eriksson, K. (2019). "Moving North and into Jail? The Great Migration and Black Incarceration". Journal of Economic Behavior \& Organization 159, 526-538.

Farber, H. S., D. Herbst, I. Kuziemko, and S. Naidu (2021). Unions and Inequality over the Twentieth Century: New Evidence from Survey Data*. The Quarterly Journal of Economics. qjab012.

Feigenbaum, J. J. and A. B. Hall (2015). "How Legislators Respond to Localized Economic Shocks: Evidence from Chinese Import Competition". The Journal of Politics r7(4), 1012-1030.

Feigenbaum, J. J., S. Mazumder, and C. B. Smith (2020). "When Coercive Economies Fail: The Political Economy of the US South After the Boll Weevil". Working Paper 27161, NBER.

Feinstein, B. D. and E. Schickler (2008). "Platforms and Partners: The Civil Rights Realignment Reconsidered". Studies in American Political Development 22(1), 1.

Fouka, V., S. Mazumder, and M. Tabellini (2021). "From Immigrants to Americans: Race and Assimilation during the Great Migration". The Review of Economic Studies. Forthcoming. 
Frymer, P. and J. M. Grumbach (2020). "Labor Unions and White Racial Politics". American Journal of Political Science.

Gardner, J. and W. Cohen (1992). "Demographic Characteristics of the Population of the United States, 1930-1950: County-Level". Ann Arbor, MI: Interuniversity Consortium for Political and Social Research [distributor], 1992-02-16. https://doi.org/10.3886/ICPSR00020.v1.

Gentzkow, M. (2016). "Polarization in 2016". Toulouse Network for Information Technology Whitepaper.

Gibson, C. and K. Jung (2005). Historical Census Statistics on Population Totals by Race, 1790 to 1990, and by Hispanic Origin, 1970 to 1990, for Large Cities and Other Urban Places in the United States. Citeseer.

Goldsmith-Pinkham, P., I. Sorkin, and H. Swift (2020). "Bartik Instruments: What, When, Why, and How". American Economic Review 110(8), 2586-2624.

Grant, K. (2020). Relocation \& Realignment: How the Great Migration Changed the Face of the Democratic Party. Temple University Press.

Gregory, J. N. (1995). "The Southern Diaspora and the Urban Dispossessed: Demonstrating the Census Public Use Microdata Samples". The Journal of American History 82(1), 111-134.

Gregory, J. N. (2006). The Southern Diaspora: How the Great Migrations of Black and White Southerners Transformed America. University of North Carolina Press.

Gregory, J. N. and J. Estrada (2019). "NAACP History and Geography. Mapping American Social Movement".

Gregory, J. N. and A. Hermida (2019). "Congress of Racial Equality (CORE) Actions, 1942-1972. Mapping American Social Movement".

Grosfeld, I., S. O. Sakalli, and E. Zhuravskaya (2020). "Middleman Minorities and Ethnic Violence: Anti-Jewish Pogroms in the Russian Empire". The Review of Economic Studies 87(1), 289-342.

Grossman, J. R. (1991). Land of Hope: Chicago, Black Southerners, and the Great Migration. University of Chicago Press.

Grove, W. A. and C. Heinicke (2003). "Better Opportunities or Worse? The Demise of Cotton Harvest Labor, 1949-1964". The Journal of Economic History 63(3), $736-767$.

Haines, M. R. et al. (2010). "Historical, Demographic, Economic, and Social Data: the United States, 1790-2002". Ann Arbor, MI: Inter-university Consortium for Political and Social Research. 
Jaeger, D. A., J. Ruist, and J. Stuhler (2018). "Shift-share Instruments and the Impact of Immigration". Working paper 24285, NBER.

Jones, D. B. and R. Walsh (2018). "How Do Voters Matter? Evidence from US Congressional Redistricting". Journal of Public Economics 158, 25-47.

Katznelson, I. and J. S. Lapinski (2006). "The Substance of Representation: Studying Policy Content and Legislative Behavior". In The Macropolitics of Congress, pp. 96-126. Princeton University Press Princeton, NJ.

Kaufman, A., G. King, and M. Komisarchik (2017). "How to Measure Legislative District Compactness if you only know it When you see it". American Journal of Political Science.

Kousser, J. M. (2010). "The Immutability of Categories and The Reshaping of Southern Politics". Annual Review of Political Science 13, 365-383.

Kroth, V., V. Larcinese, and J. Wehner (2016). "A Better Life for All? Democratization and Electrification in Post-apartheid South Africa". The Journal of Politics 78(3), 774-791.

Kuziemko, I. and E. Washington (2018). "Why Did the Democrats Lose the South? Bringing New Data to an Old Debate". American Economic Review 108(10), 283067.

Lawson, S. F. (1976). Black Ballots: Voting Rights in the South, 1944-1969. Columbia University Press.

Logan, T. D. and J. M. Parman (2017). "The National Rise in Residential Segregation". The Journal of Economic History 7r(1), 127-170.

Lott, Jr, J. R. and L. W. Kenny (1999). "Did Women's Suffrage Change the Size and Scope of Government?". Journal of political Economy 107(6), 1163-1198.

Lowe, M. (2021). "Types of Contact: A Field Experiment on Collaborative and Adversarial Caste Integration". American Economic Review 111 (6), 1807-44.

Margo, R. A. (1991). "Segregated Schools and the Mobility Hypothesis: a Model of Local Government Discrimination". The Quarterly Journal of Economics 106(1), $61-73$.

McAdam, D. (1982). Political Process and the Development of Black Insurgency, 19301970. Chicago and London: University of Chicago Press.

Mian, A., A. Sufi, and F. Trebbi (2010). "The Political Economy of the US Mortgage Default Crisis". American Economic Review 100(5), 1967-98. 
Miller, G. (2008). "Women's Suffrage, Political Responsiveness, and Child Survival in American History". The Quarterly Journal of Economics 123(3), 1287-1327.

Moon, H. L. (1948). Balance of Power: The Negro Vote. Greenwood Publishing Group.

Muller, C. (2012). "Northward Migration and the Rise of Racial Disparity in American Incarceration, 1880-1950". American Journal of Sociology 118(2), 281-326.

Myrdal, G. (1944). An American Dilemma: the Negro Problem and Modern Democracy. Harper and Row, Publishers.

Neal, D. A. and W. R. Johnson (1996). "The Role of Premarket Factors in Black-White Wage Differences". Journal of political Economy 104(5), 869-895.

Oster, E. (2004). "Witchcraft, Weather and Economic Growth in Renaissance Europe". Journal of Economic Perspectives 18(1), 215-228.

Pearson, K. and E. Schickler (2009). "Discharge Petitions, Agenda Control, and the Congressional Committee System, 1929-76". The Journal of Politics 71(4), 12381256.

Peri, G. and C. Sparber (2011). "Assessing Inherent Model Bias: An Application to Native Displacement in Response to Immigration". Journal of Urban Economics 69(1), 82-91.

Pons, V. (2018). "Will a Five-minute Discussion Change Your Mind? A Countrywide Experiment on Voter Choice in France". American Economic Review 108(6), 1322 63.

Poole, K. T. and H. Rosenthal (1985). "A Spatial Model for Legislative Roll Call Analysis". American Journal of Political Science 29(2), 357-384.

Qian, N. and M. Tabellini (2020). "Discrimination, Disenfranchisement and African American WWII Military Enlistment".

Rao, G. (2019). "Familiarity does not Breed Contempt: Generosity, Discrimination, and Diversity in Delhi Schools". American Economic Review 109(3), 774-809.

Reber, S. J. (2011). "From Separate and Unequal to Integrated and Equal? School Desegregation and School Finance in Louisiana". The Review of Economics and Statistics 93(2), 404-415.

Reny, T. T. and B. J. Newman (2018). "Protecting the Right to Discriminate: The Second Great Migration and Racial Threat in the American West". American Political Science Review 112(4), 1104-1110.

Ruggles, S., K. Genadek, R. Goeken, J. Grover, and M. Sobek (2015). Integrated Public Use Microdata Series: Version 6.0 [dataset]. Minneapolis: University of Minnesota. 
Schickler, E. (2016). Racial Realignment: The Transformation of American Liberalism, 1932-1965. Princeton University Press.

Schindler, D. and M. Westcott (2020). "Shocking Racial Attitudes: Black G.I.s in Europe". The Review of Economic Studies 88(1), 489-520.

Sequeira, S., N. Nunn, and N. Qian (2020). "Immigrants and the Making of America". Review of Economic Studies 87(1), 382-419.

Shertzer, A. and R. P. Walsh (2019). "Racial Sorting and the Emergence of Segregation in American Cities". Review of Economics and Statistics 101(3), 1-14.

Smith, J. P. and F. R. Welch (1989). "Black Economic Progress After Myrdal". Journal of economic literature $27(2), 519-564$.

Snyder, J. M. and S. Ansolabehere (2008). The End of Inequality: One Person, One Vote and the Reshaping of American Politics. WW Norton and Company.

Steinmayr, A. (2020). "Contact versus Exposure: Refugee Presence and Voting for the Far-Right". Review of Economics and Statistics, 1-47.

Sugrue, T. J. (2008). Sweet Land of Liberty: The Forgotten Struggle for Civil Rights in the North. Random House.

Sugrue, T. J. (2014). The Origins of the Urban Crisis: Race and Inequality in Postwar Detroit-Updated Edition. Princeton University Press.

Swift, E. K., R. G. Brookshire, D. T. Canon, E. C. Fink, J. R. Hibbing, B. D. Humes, M. J. Malbin, and K. C. Martis (2000). Database of Congressional Historical Statistics [computer file]. Ann Arbor, MI: Inter-university Consortium for Political and Social Research.

Tabellini, M. (2018). "Racial Heterogeneity and Local Government Finances: Evidence from the Great Migration". Working Paper No. 19-006, Harvard Business School BGIE Unit.

Tabellini, M. (2020). "Gifts of The Immigrants, Woes of The Natives: Lessons from The Age of Mass Migration". Review of Economic Studies 87(1), 454-486.

Tiebout, C. M. (1956). "A Pure Theory of Local Expenditures". Journal of political economy 64 (5), 416-424.

Tolbert, C. M. and M. Sizer (1996). US Commuting Zones and Labor Market Areas: A 1990 Update. Technical report.

Trende, S. (2012). The Lost Majority: Why the Future of Government Is Up for Grabs-and Who Will Take It. St. Martin's Press. 
Troy, L. (1957). "Distribution of Union Membership among the States, 1939 and 1953". NBER Books.

Voigtländer, N. and H.-J. Voth (2012). "Persecution Perpetuated: the Medieval Origins of anti-Semitic Violence in Nazi Germany". The Quarterly Journal of Economics 127(3), 1339-1392.

Wasow, O. (2020). "Agenda Seeding: How 1960s Black Protests Moved Elites, Public Opinion and Voting". American Political Science Review, 1-22.

Whatley, W. C. (1985). "A History of Mechanization in the Cotton South: the Institutional Hypothesis". The Quarterly Journal of Economics 100(4), 1191-1215.

Wheaton, B. (2020). "Laws, Beliefs, and Backlash". Working Paper.

Wright, G. (2013). Sharing the Prize. Harvard University Press.

Zieger, R. H. (2000). The CIO, 1935-1955. University of North Carolina Press. 


\section{Figures and Tables}

Figure 1. Change in the Black Share across US Counties, 1940 to 1970

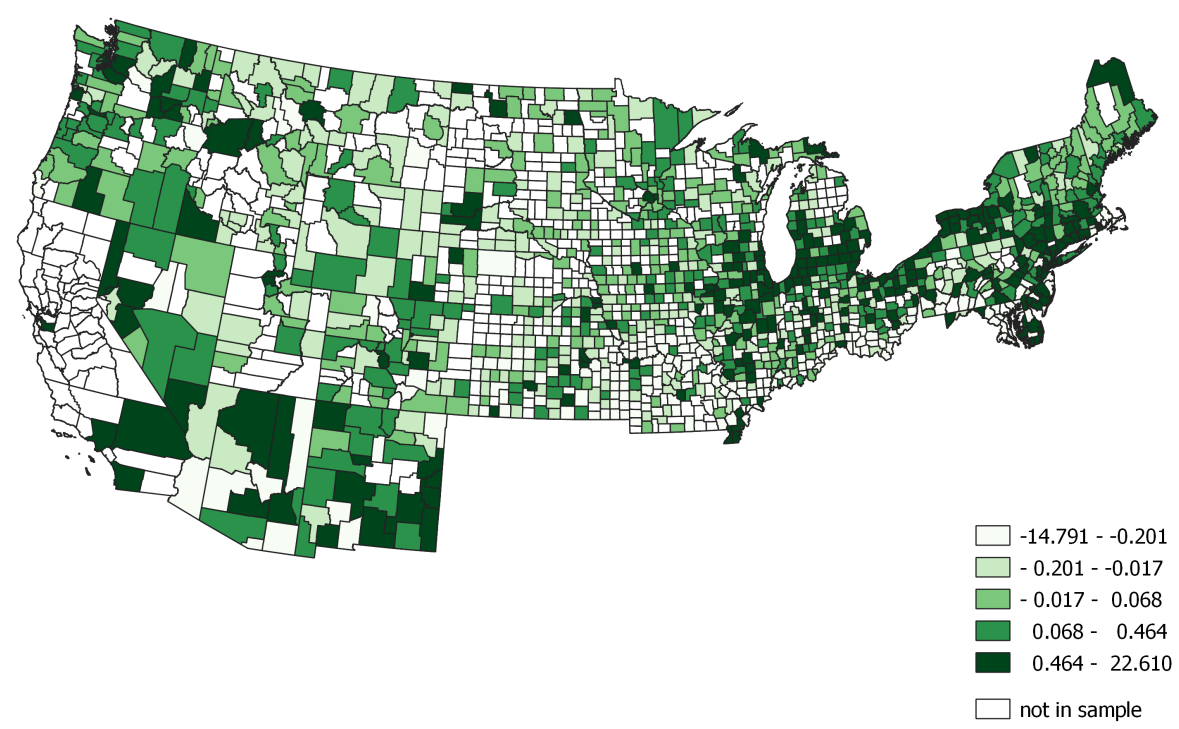

Notes: The map plots the change in the share of Black individuals in the population between 1940 and 1970 for the non-southern counties $(1,263)$ in our sample. 
Figure 2. Heterogeneity by County Characteristics - Political and Economic Forces

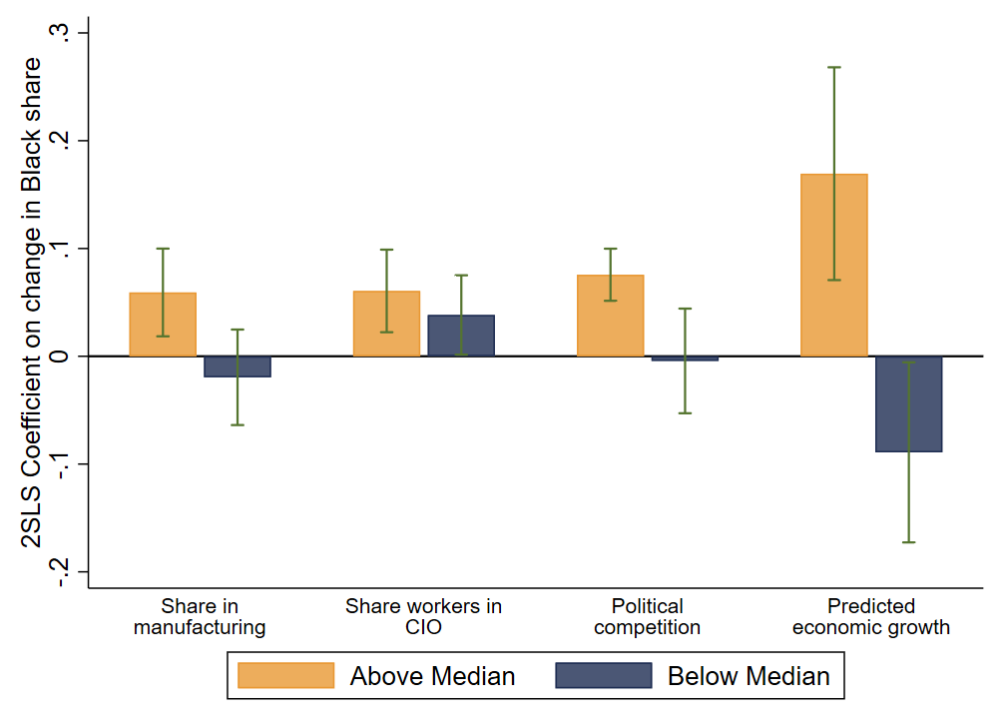

Notes: The bars report the marginal effect of changes in the Black share (with corresponding $95 \%$ confidence intervals) on the change in the probability of non-violent demonstrations in support of civil rights for counties with each 1940 variable above (resp. below) the sample median in orange (resp. blue). Section 5.3.2 describes how each variable is constructed. Coefficients and standard errors reported in Table A.6.

Figure 3. Heterogeneity by County Characteristics - Social and Cultural Forces

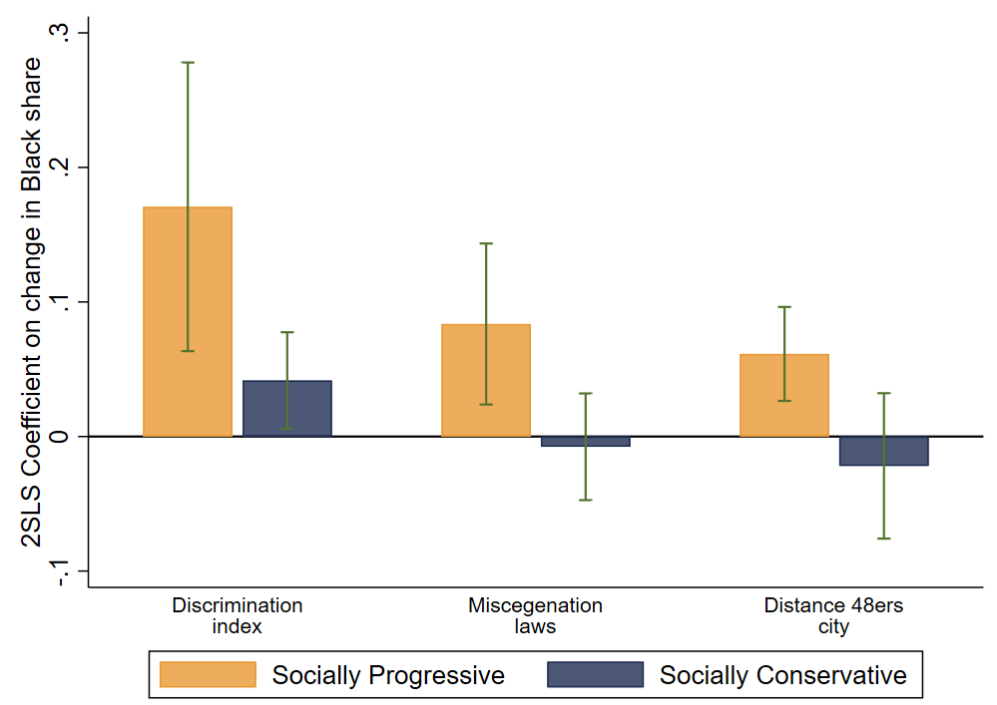

Notes: The bars report the marginal effect of changes in the Black share (with corresponding $95 \%$ confidence intervals) on the change in the probability of non-violent demonstrations in support of civil rights for counties that are more (resp. less) socially progressive in orange (resp. blue). Section 5.3.2 describes how each variable is constructed. Coefficients and standard errors reported in Table A.6. 


\section{Figure 4. Newspapers - Event Study}

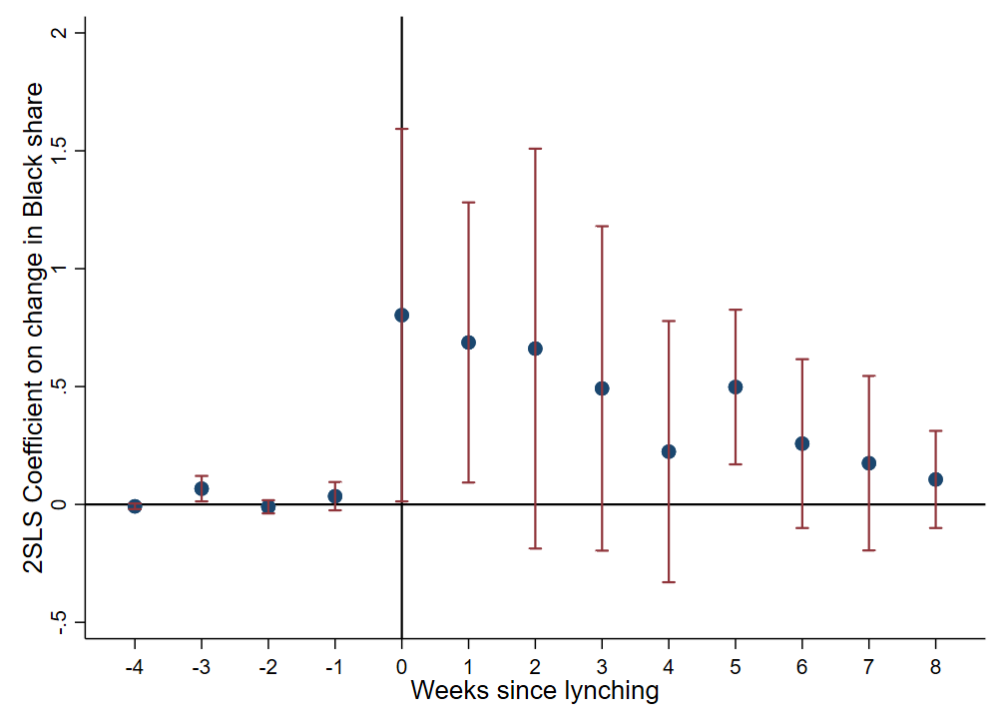

Notes: The figure plots 2SLS coefficients (with corresponding 95\% intervals) on the 1940-1960 change in the Black share in county-week level regressions where the dependent variable is a dummy equal to one if any mention about the lynching of a Black individual in the US South appeared in newspapers of the (nonsouthern) county in each week. Week 0 refers to the week when the lynching occurred. See the main text for more details. All regressions control for state and lynching episode fixed effects, and are weighed by 1940 county population. Standard errors are clustered at the county level.

\section{Figure 5. Change in Signatures on Discharge Petitions}

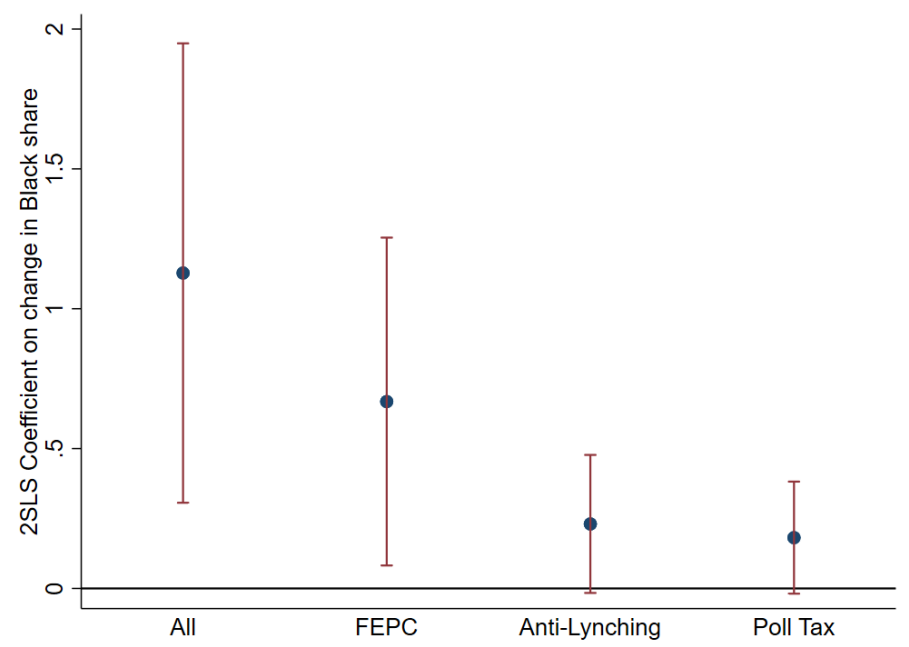

Notes: The figure plots the 2SLS coefficient (with corresponding 95\% confidence intervals) for the effects of the 1940-1950 change in the Black share on the corresponding change in the number of signatures on discharge petitions per legislator. The first dot on the left ("All") includes discharge petitions on employment protection legislation (FEPC), to promote anti-lynching legislation, and to abolish the poll tax. The three remaining dots refer to each of the three issues. Results and details of the specification are reported in Table A.10. 
Figure 6. Black in-Migration and Political Polarization

Panel A: 1940s

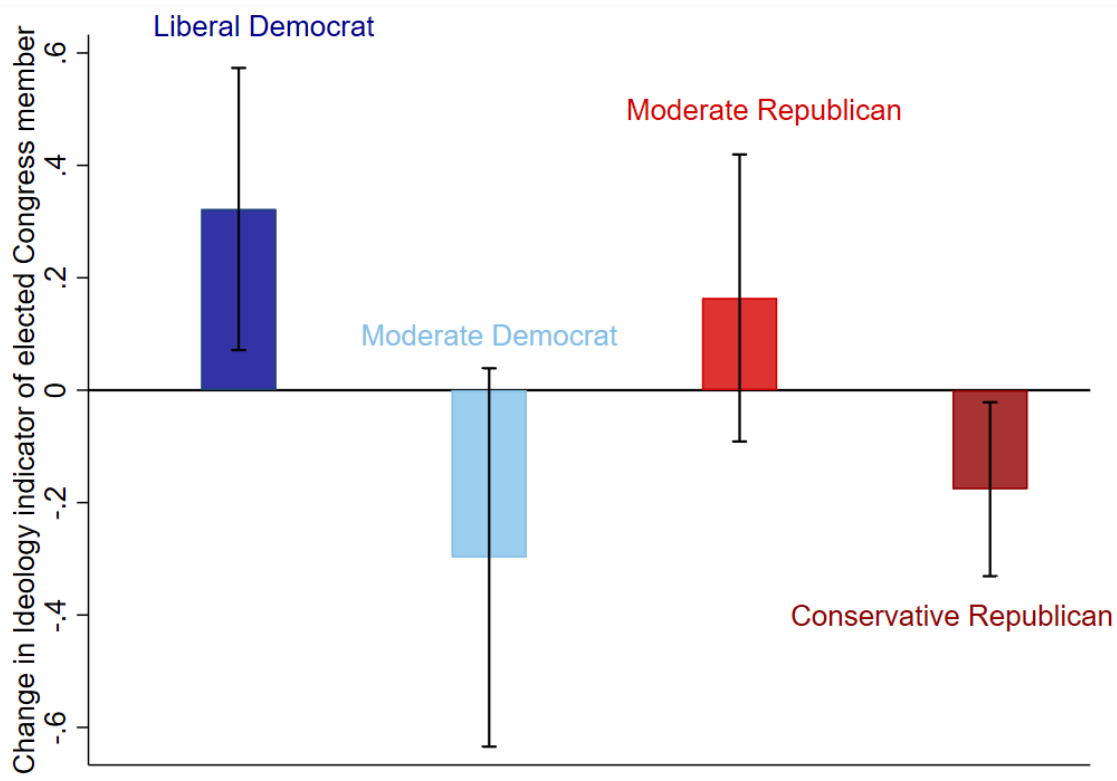

Panel B: 1950s

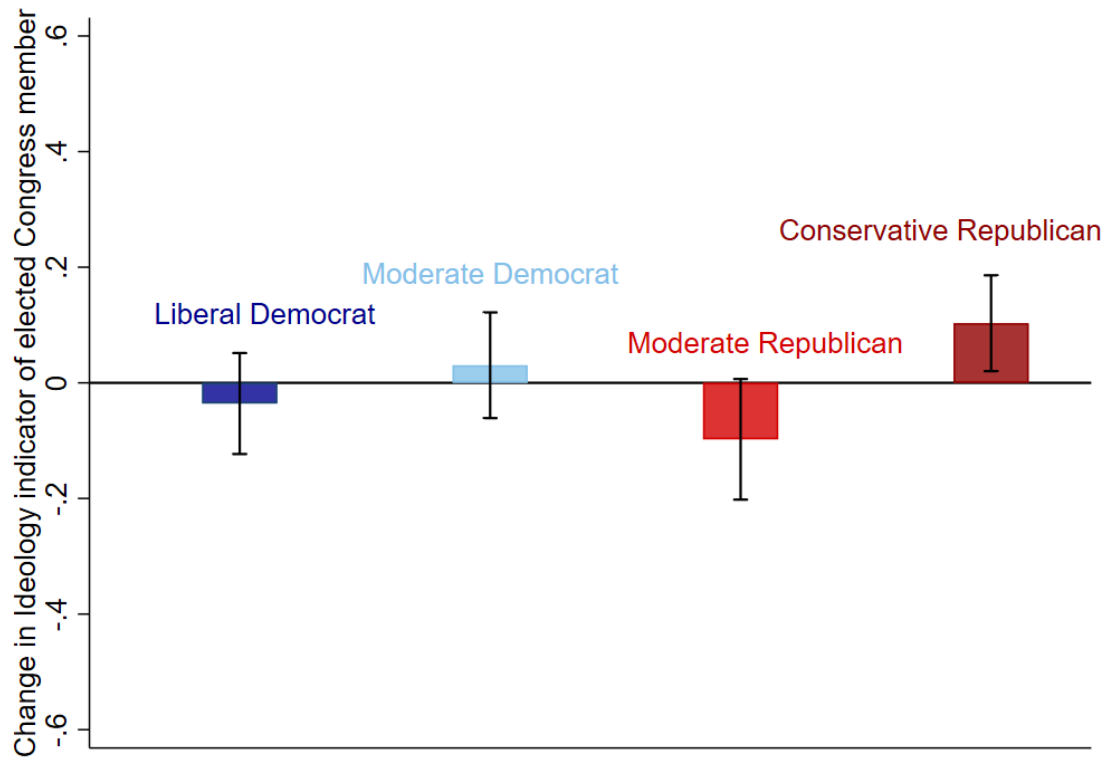

Notes: Each bar reports 2SLS coefficients (with corresponding 95\% confidence intervals) for the effect of changes in the Black share on the change in the probability of electing a member of the House with the corresponding political orientation between Congress 78 and Congress 82 (Panel A) and between Congress 82 and Congress 88 (Panel B). The ideology indicators are defined in the main text (Section 6.2). 
Table 1. Summary Statistics

\begin{tabular}{lcccccc}
\hline \multicolumn{1}{c}{ Variables } & Mean & Median & St. Dev. & Min & Max & Obs \\
\hline Panel A: 1940 levels & & & & & & \\
Black Share (County) & 3.60 & 2.10 & 0.04 & 0 & 46.50 & 1,263 \\
Black Share (CD) & 6.80 & 7.20 & 0.047 & 0 & 25.40 & 285 \\
Democratic Vote Share & 46.55 & 49.00 & 12.91 & 0 & 85.00 & 1,263 \\
Turnout & 69.39 & 69.60 & 8.29 & 23.00 & 97.90 & 1,263 \\
Civil Rights Scores & -0.87 & -0.81 & 0.71 & -2.01 & 1.43 & 285 \\
& & & & & & \\
Panel B: Changes & 1.78 & 0.72 & 2.53 & -11.88 & 12.79 & 3,789 \\
Black Share (County) & 5.25 & 5.58 & 2.81 & -1.26 & 12.86 & 570 \\
Black Share (CD) & 1.53 & 0.67 & 11.11 & -67.19 & 72.80 & 3,789 \\
Democratic Vote Share & -6.49 & -13.50 & 17.06 & -64.30 & 43.00 & 3,789 \\
Turnout & 0.07 & 0 & 0.71 & -2.91 & 1.95 & 570 \\
Civil Rights Scores & & & & & & \\
\hline
\end{tabular}

Notes: The sample includes the 1,263 non-southern US counties (see Table A.1 for our definition of southern states) for which electoral returns in Congressional elections are available for all Census years between 1940 and 1970, and with at least one African American resident in 1940. When relevant, county variables are collapsed at the Congressional District level, fixing boundaries to Congress 78 as explained in the text. Democratic vote share and turnout refer to Congressional elections, and civil rights scores are the ideology scores from Bateman et al. (2017). Panel A presents 1940 values, while Panel B reports decadal changes for each of the variables. 
Table 2. Congressional Elections

\begin{tabular}{|c|c|c|c|c|c|c|c|}
\hline Dependent Variable & $\begin{array}{l}(1) \\
\text { OLS }\end{array}$ & $\begin{array}{c}(2) \\
\text { OLS }\end{array}$ & $\begin{array}{c}(3) \\
\text { OLS }\end{array}$ & $\begin{array}{c}(4) \\
2 \mathrm{SLS}\end{array}$ & $\begin{array}{c}(5) \\
2 \mathrm{SLS}\end{array}$ & $\begin{array}{c}(6) \\
2 \mathrm{SLS}\end{array}$ & $\begin{array}{c}(7) \\
2 \mathrm{SLS}\end{array}$ \\
\hline \multicolumn{8}{|c|}{ Panel A: Change in Democratic Vote Share (1940 mean: 46.55) } \\
\hline $\begin{array}{l}\text { Change Black } \\
\text { Share }\end{array}$ & $\begin{array}{c}0.537^{* * * *} \\
(0.108)\end{array}$ & $\begin{array}{c}0.538^{* * *} \\
(0.124)\end{array}$ & $\begin{array}{c}0.611^{* * * *} \\
(0.146)\end{array}$ & $\begin{array}{c}0.712^{* * *} \\
(0.162)\end{array}$ & $\begin{array}{c}1.255^{* * *} \\
(0.277)\end{array}$ & $\begin{array}{c}1.885^{* * *} \\
(0.439)\end{array}$ & $\begin{array}{c}1.938^{* * *} \\
(0.464)\end{array}$ \\
\hline \multicolumn{8}{|c|}{ Panel B: Change in Turnout (1940 mean: 69.39) } \\
\hline $\begin{array}{l}\text { Change Black } \\
\text { Share }\end{array}$ & $\begin{array}{c}-0.274^{* *} \\
(0.121)\end{array}$ & $\begin{array}{c}-0.298^{* * *} \\
(0.112)\end{array}$ & $\begin{array}{c}-0.293^{* * *} \\
(0.109)\end{array}$ & $\begin{array}{c}0.094 \\
(0.187)\end{array}$ & $\begin{array}{l}0.399^{*} \\
(0.235)\end{array}$ & $\begin{array}{c}0.756^{* *} \\
(0.348)\end{array}$ & $\begin{array}{c}0.809^{* *} \\
(0.356)\end{array}$ \\
\hline \multicolumn{8}{|l|}{ Panel C: First stage } \\
\hline $\begin{array}{l}\text { Predicted Change } \\
\text { Black Share }\end{array}$ & & & & $\begin{array}{c}0.976^{* * *} \\
(0.261)\end{array}$ & $\begin{array}{c}1.002^{* * *} \\
(0.260)\end{array}$ & $\begin{array}{c}0.758^{* * *} \\
(0.233)\end{array}$ & $\begin{array}{c}0.803^{* * *} \\
(0.249)\end{array}$ \\
\hline $\begin{array}{l}\text { Specification } \\
1940 \text { Black Share } \\
1940 \text { Dem Incumbent }\end{array}$ & $\mathrm{FD}$ & $\begin{array}{l}\text { FD } \\
\mathrm{X}\end{array}$ & $\begin{array}{l}\text { FD } \\
\mathrm{X} \\
\mathrm{X}\end{array}$ & FD & $\begin{array}{c}\text { FD } \\
\mathrm{X}\end{array}$ & $\begin{array}{l}\mathrm{FD} \\
\mathrm{X} \\
\mathrm{X}\end{array}$ & $\begin{array}{l}\mathrm{LD} \\
\mathrm{X} \\
\mathrm{X}\end{array}$ \\
\hline $\begin{array}{l}\text { F-Stat } \\
\text { Observations }\end{array}$ & 3,789 & 3,789 & 3,789 & $\begin{array}{l}13.95 \\
3,789\end{array}$ & $\begin{array}{l}14.88 \\
3,789\end{array}$ & $\begin{array}{l}10.57 \\
3,789\end{array}$ & $\begin{array}{l}10.42 \\
1,263\end{array}$ \\
\hline
\end{tabular}

Notes: The sample includes the 1,263 non-southern US counties (see Table A.1 for the definition of southern states) for which electoral returns in Congressional elections are available for all Census years between 1940 and 1970 , and with at least one African American resident in 1940. The table reports stacked first difference regressions in columns 1 to 6 , and long difference regressions in column 7 . The dependent variable is the decadal change in the Democratic vote share (resp. turnout) in Congressional elections in Panel A (resp. Panel B). Panel C reports the first stage associated with 2SLS regressions. Columns 1 to 3 estimate equation (1) in the text with OLS, while remaining columns report 2SLS estimates. The main regressor of interest is the change in the Black share, which is instrumented with the shift-share instrument described in equation (2) in the text from column 4 onwards. All regressions are weighed by 1940 county population, and control for state by period fixed effects. 1940 Black share (resp. 1940 Dem Incumbent) refers to interactions between period dummies and the 1940 Black share (resp. a dummy equal to 1 if the Democratic vote share in 1940 was higher than the Republicans vote share). F-stat is the K-P F-stat for weak instruments. Robust standard errors, clustered at the county level, in parentheses. Significance levels: ${ }^{* * *} \mathrm{p}<0.01,{ }^{* *} \mathrm{p}<0.05,{ }^{*}$ $\mathrm{p}<0.1$. 
Table 3. CORE Demonstrations

\begin{tabular}{|c|c|c|c|c|c|c|c|}
\hline \multirow[t]{3}{*}{ Dependent Variable } & \multicolumn{7}{|c|}{ Change in 1 [Pro-Civil Rights Demonstration] } \\
\hline & $(1)$ & $(2)$ & $(3)$ & $(4)$ & $(5)$ & $(6)$ & $(7)$ \\
\hline & OLS & OLS & OLS & 2SLS & 2SLS & 2SLS & 2SLS \\
\hline \multicolumn{8}{|c|}{ Panel A: Main Estimates } \\
\hline Change Black & $0.033^{* * *}$ & $0.024^{* * *}$ & $0.025^{* * *}$ & $0.075^{* * *}$ & $0.053^{* * *}$ & $0.057^{* * *}$ & $0.033^{* *}$ \\
\hline Share & $(0.007)$ & $(0.007)$ & $(0.007)$ & $(0.014)$ & $(0.013)$ & $(0.018)$ & $(0.016)$ \\
\hline \multicolumn{8}{|l|}{ Panel B: First Stage } \\
\hline Predicted Change & & & & $0.976^{* * *}$ & $1.002^{* * *}$ & $0.758^{* * *}$ & $0.758^{* * *}$ \\
\hline Black Share & & & & $(0.261)$ & $(0.260)$ & $(0.233)$ & $(0.233)$ \\
\hline 1940 Black Share & & $\mathrm{X}$ & $\mathrm{X}$ & & $\mathrm{X}$ & $\mathrm{X}$ & $\mathrm{X}$ \\
\hline 1940 Dem Incumbent & & & $\mathrm{X}$ & & & $\mathrm{X}$ & $\mathrm{X}$ \\
\hline White Participants & & & & & & & $\mathrm{X}$ \\
\hline F-Stat & & & & 13.95 & 14.88 & 10.57 & 10.57 \\
\hline Observations & 3,789 & 3,789 & 3,789 & 3,789 & 3,789 & 3,789 & 3,789 \\
\hline
\end{tabular}

Notes: The sample includes the 1,263 non-southern US counties (see Table A.1 for the definition of southern states) for which electoral returns in Congressional elections are available for all Census years between 1940 and 1970 , and with at least one African American resident in 1940. The dependent variable is the change in the probability of non-violent demonstrations in support of civil rights coordinated by the CORE. Columns 1 to 3 estimate equation (1) in the text with OLS, while remaining columns report 2SLS estimates. The main regressor of interest is the change in the Black share, which is instrumented with the shift-share instrument described in equation (2) in the text from column 4 onwards. All regressions are weighed by 1940 county population, and control for state by period fixed effects. 1940 Black share (resp. 1940 Dem Incumbent) refers to interactions between period dummies and the 1940 Black share (resp. a dummy equal to 1 if the Democratic vote share in 1940 was higher than the Republicans vote share). Column 7 includes only those demonstrations that were joined by at least some white participants. F-stat is the K-P F-stat for weak instruments. Robust standard errors, clustered at the county level, in parentheses. Significance levels: ${ }^{* * *} \mathrm{p}<0.01,{ }^{* *} \mathrm{p}<0.05,{ }^{*} \mathrm{p}<0.1$. 
Table 4. NAACP Chapters

\begin{tabular}{|c|c|c|c|c|}
\hline \multirow[t]{3}{*}{ Dependent Variable } & \multicolumn{4}{|c|}{ 1940-1960 Change in 1[NAACP Chapter] } \\
\hline & $(1)$ & $(2)$ & $(3)$ & $(4)$ \\
\hline & OLS & OLS & 2SLS & 2SLS \\
\hline \multicolumn{5}{|l|}{ Panel A: Main Estimates } \\
\hline Change Black Share & $\begin{array}{c}-0.022^{* *} \\
(0.008)\end{array}$ & $\begin{array}{c}0.051^{* * *} \\
(0.016)\end{array}$ & $\begin{array}{l}-0.029 \\
(0.024)\end{array}$ & $\begin{array}{l}0.070^{* *} \\
(0.035)\end{array}$ \\
\hline \multicolumn{5}{|l|}{ Panel B: First Stage } \\
\hline Predicted Change Black & & & $0.780^{* * *}$ & $0.624^{* *}$ \\
\hline Share & & & $(0.231)$ & $(0.247)$ \\
\hline F-stat & & & 11.41 & 6.392 \\
\hline Observations & 1,263 & 1,069 & 1,263 & 1,069 \\
\hline Sample & Full sample & $\begin{array}{l}\text { No NAACP } \\
\text { in } 1940\end{array}$ & Full sample & $\begin{array}{c}\text { No NAACP } \\
\quad \text { in } 1940\end{array}$ \\
\hline
\end{tabular}

Notes: The sample includes the 1,263 non-southern US counties (see Table A.1 for the definition of southern states) for which electoral returns in Congressional elections are available for all Census years between 1940 and 1970 , and with at least one African American resident in 1940. The dependent variable is the change (between 1940 and 1960$)$ in the presence of NAACP chapters. Columns 2 and 4 restrict attention to counties with no NAACP chapter in 1940. Columns 1 and 2 estimate OLS regressions, whereas columns 3 and 4 present 2SLS results. The main regressor of interest is the 1940-1960 Change Black Share, and is instrumented with the shift-share instrument constructed in the text in columns 3 and 4. All regressions are weighed by 1940 county population, and include: $i$ ) state fixed effects; ii) the 1940 Black share; and iii) a dummy equal to 1 if the Democratic vote share in 1940 was higher than the Republican vote share. F-stat is the K-P F-stat for weak instruments. Robust standard errors, clustered at the county level, in parentheses. Significance levels: ${ }^{* * *} \mathrm{p}<0.01,{ }^{* *} \mathrm{p}<0.05,{ }^{*} \mathrm{p}<0.1$. 
Table 5. Whites' Most Important Problem (ANES)

\begin{tabular}{|c|c|c|c|c|c|}
\hline \multirow[t]{3}{*}{ Dependent Variable } & \multicolumn{5}{|c|}{ 1[Pro Civil Rights: Most Important Problem] } \\
\hline & $(1)$ & $(2)$ & $(3)$ & $(4)$ & $(5)$ \\
\hline & OLS & OLS & OLS & OLS & 2SLS \\
\hline \multicolumn{6}{|l|}{ Panel A: Main Estimates } \\
\hline $1[$ Pro Segregation $]$ & $\begin{array}{c}-0.059^{* *} \\
(0.022)\end{array}$ & & & & \\
\hline $\begin{array}{l}\text { 1[Against School } \\
\text { Integration] }\end{array}$ & & $\begin{array}{c}-0.071^{* * *} \\
(0.024)\end{array}$ & & & \\
\hline $\begin{array}{l}\text { 1[Against Housing/Work } \\
\text { Integration] }\end{array}$ & & & $\begin{array}{l}-0.064 \\
(0.038)\end{array}$ & & \\
\hline Change Black Share & & & & $\begin{array}{c}0.015 \\
(0.013)\end{array}$ & $\begin{array}{l}0.034^{* *} \\
(0.014)\end{array}$ \\
\hline \multicolumn{6}{|l|}{ Panel B: First Stage } \\
\hline Predicted Change & & & & & $2.748^{* * *}$ \\
\hline Black Share & & & & & $(0.439)$ \\
\hline Geography FE & State & State & State & Region & Region \\
\hline State Controls & & & & $\mathrm{X}$ & $\mathrm{X}$ \\
\hline F-Stat & & & & & 39.20 \\
\hline Observations & 909 & 811 & 813 & 927 & 927 \\
\hline Mean Dependent Variable & 0.112 & 0.113 & 0.112 & 0.111 & 0.111 \\
\hline
\end{tabular}

Notes: The sample is restricted to white ANES respondents living in the US North in years 1960 and 1964 , and residing in their state of birth. The dependent variable is a dummy equal to 1 if the respondent reports that supporting civil rights is among the most important issues facing the country at the time of the interview (see online appendix D for exact wording and additional details on the construction of the variable). The regressor of interest in column 2 (resp. column 3) is a dummy equal to 1 if the respondent is against the integration of schools (resp. of working environment and housing). Pro-segregation in column 1 is a dummy if the respondent is either against school integration or against working-housing integration. Change Black share (columns 4 and 5) is the change in the Black share at the state level between 1940 and 1960. Column 4 reports OLS estimates, while column 5 presents 2SLS estimates, instrumenting the change in the Black share with the predicted number of Black migrants over 1940 state population. Panel B reports the first stage. All regressions include survey year fixed effects and individual controls of respondents (gender, age and education fixed effects and marital status). Columns 1 to 3 control for state fixed effects, while columns 4 and 5 control for region fixed effects and 1940 state characteristics (Black share; Democratic incumbency in Congressional elections; share in manufacturing; share of workers in the CIO; urban share). The bottom row reports the average of the dependent variable. F-stat in column 5 is the K-P F-stat for weak instruments. Robust standard errors, clustered at the state level, in parentheses. ${ }^{* * *} \mathrm{p}<0.01,{ }^{* *} \mathrm{p}<0.05,{ }^{*} \mathrm{p}<0.1$. 
Table 6. Evidence from Northern Newspapers: Cross-sectional Regressions

\begin{tabular}{lccccc}
\hline Dependent Variable & \multicolumn{5}{c}{ 1[Any Mention] } \\
\cline { 2 - 6 } & $(1)$ & $(2)$ & $(3)$ & $(4)$ & $(5)$ \\
\hline Panel A: Main Estimates & & & & \\
Change Black Share & $0.253^{* *}$ & 0.135 & $0.348^{* *}$ & $0.532^{* *}$ & $0.677^{* *}$ \\
& $(0.128)$ & $(0.086)$ & $(0.163)$ & $(0.235)$ & $(0.301)$ \\
& & & & \\
Panel B: First Stage & & & & \\
Predicted Change & $1.071^{* * *}$ & $1.032^{* * *}$ & $1.098^{* * *}$ & $1.093^{* * *}$ & $1.081^{* * *}$ \\
Black Share & $(0.289)$ & $(0.287)$ & $(0.291)$ & $(0.291)$ & $(0.289)$ \\
& & & & & \\
F-stat & 13.76 & 12.95 & 14.26 & 14.08 & 13.96 \\
Observations & 311,803 & 141,332 & 170,471 & 79,721 & 59,665 \\
State FE & $\mathrm{X}$ & $\mathrm{X}$ & $\mathrm{X}$ & $\mathrm{X}$ & $\mathrm{X}$ \\
Episode FE & $\mathrm{X}$ & $\mathrm{X}$ & $\mathrm{X}$ & $\mathrm{X}$ & $\mathrm{X}$ \\
Week FE & $\mathrm{X}$ & $\mathrm{X}$ & $\mathrm{X}$ & $\mathrm{X}$ & $\mathrm{X}$ \\
Weeks & $0 \mathrm{to} 26$ & 0 to 26 & 0 to 26 & 0 to 26 & 0 to 26 \\
Sample & $1940+$ & $1940-1944$ & $1945+$ & $1950+$ & $1955+$ \\
\hline
\end{tabular}

Notes: The sample is restricted to the 492 counties in our sample for which newspapers' data were available. The table reports county-week-episode level regressions where the dependent variable is a dummy equal to 1 if at least one mention about the lynching of a Black individual in the US South appeared in the local newspapers of the county in each week from 0 to 26 . Week 0 is defined as the week in which the lynching occurred. The main regressor of interest is the 1940 to 1960 change in the Black share in the county, and is instrumented with the shift-share instrument described in equation (2) in the text. All regressions include state, week, and episode fixed effects, and are weighed by 1940 county population. The last row of the table indicates the sample of lynchings considered. When the last year is not specified, it corresponds to 1964 (included). F-stat refers to the K-P F-stat for weak instruments. Robust standard errors, clustered at the county level, in parentheses. Significance levels: ${ }^{* * *} \mathrm{p}<0.01,{ }^{* *} \mathrm{p}<0.05,{ }^{*} \mathrm{p}<0.1$. 
Table 7. Evidence from Northern Newspapers: Event-Study Design

\begin{tabular}{|c|c|c|c|c|c|c|}
\hline \multirow[t]{2}{*}{ Dependent Variable } & \multicolumn{6}{|c|}{$1[$ Any Mention $]$} \\
\hline & (1) & $(2)$ & $(3)$ & (4) & $(5)$ & $(6)$ \\
\hline \multicolumn{7}{|c|}{ Panel A. 1940-1960 Change in Black Share } \\
\hline Change Black Share ${ }^{*}$ POST & $\begin{array}{l}0.237^{*} \\
(0.126)\end{array}$ & $\begin{array}{c}0.113 \\
(0.085)\end{array}$ & $\begin{array}{c}0.325^{* *} \\
(0.162)\end{array}$ & $\begin{array}{c}0.476^{* *} \\
(0.228)\end{array}$ & $\begin{array}{c}0.691^{* *} \\
(0.306)\end{array}$ & $\begin{array}{c}1.050^{* * *} \\
(0.262)\end{array}$ \\
\hline F-stat & 13.61 & 12.76 & 14.04 & 13.78 & 13.5 & 12.87 \\
\hline Observations & 357,979 & 162,303 & 195,671 & 91,544 & 68,520 & 22,047 \\
\hline Events & $1940+$ & 1940-1944 & $1945+$ & $1950+$ & $1955+$ & $1960+$ \\
\hline \multicolumn{7}{|c|}{ Panel B. Decadal Changes in Black Share } \\
\hline Change Black Share ${ }^{*}$ POST & $\begin{array}{c}0.248 \\
(0.161)\end{array}$ & $\begin{array}{c}0.764^{* *} \\
(0.317)\end{array}$ & $\begin{array}{c}1.127^{* *} \\
(0.447)\end{array}$ & $\begin{array}{c}0.262 \\
(0.189)\end{array}$ & $\begin{array}{l}1.194^{*} \\
(0.625)\end{array}$ & $\begin{array}{c}1.825^{* * *} \\
(0.534)\end{array}$ \\
\hline F-stat & 20.96 & 22.95 & 22.51 & 8.433 & 8.624 & 8.227 \\
\hline Observations & 162,303 & 195,671 & 91,544 & 266,429 & 68,520 & 22,047 \\
\hline Change Black share & 1940-1950 & 1940-1950 & $1940-1950$ & $1950-1960$ & $1950-1960$ & $1950-1960$ \\
\hline Events & 1940-1944 & $1945+$ & $1950+$ & $1940-1949$ & $1955+$ & $1960+$ \\
\hline County FE & $\mathrm{X}$ & $\mathrm{X}$ & $\mathrm{X}$ & $\mathrm{X}$ & $\mathrm{X}$ & $\mathrm{X}$ \\
\hline Episode FE & $\mathrm{X}$ & $\mathrm{X}$ & $\mathrm{X}$ & $\mathrm{X}$ & $\mathrm{X}$ & $\mathrm{X}$ \\
\hline State-week FE & $\mathrm{X}$ & $\mathrm{X}$ & $\mathrm{X}$ & $\mathrm{X}$ & $\mathrm{X}$ & $\mathrm{X}$ \\
\hline
\end{tabular}

Notes: The sample is restricted to the 492 counties in our sample for which newspapers' data were available. The table reports county-week-episode level regressions where the dependent variable is a dummy equal to 1 if at least one mention about the lynching of a Black individual in the US South appeared in the local newspapers of the county in each week from -4 to 26 . Week 0 is defined as the week in which the lynching occurred. The main regressor of interest is the 1940 to 1960 (resp. decadal) change in the Black share in the county in Panel A (resp. Panel B) interacted with an indicator for weeks 0 and above (POST). The change in the Black share is instrumented with the shift-share instrument described in equation (2) in the text. All regressions include county, state by week, and episode fixed effects, and are weighed by 1940 county population. Columns 1 to 3 (resp. 4 to 6) of Panel B consider the 1940-1950 (resp. 1950-1960) change in the Black share. The last row of the table indicates the sample of lynchings considered. When the last year is not specified, it corresponds to 1964 (included). F-stat refers to the K-P F-stat for weak instruments. Robust standard errors, clustered at the county level, in parentheses. Significance levels: ${ }^{* * *} \mathrm{p}<0.01,{ }^{* *}$ $\mathrm{p}<0.05,{ }^{*} \mathrm{p}<0.1$. 
Table 8. Changes in Legislators' Ideology

\begin{tabular}{|c|c|c|c|c|c|c|}
\hline \multirow[t]{3}{*}{ Dependent Variable } & \multicolumn{6}{|c|}{ Change in Civil Rights Ideology (Lower Values = More Liberal Ideology) } \\
\hline & \multicolumn{3}{|c|}{$\begin{array}{c}\text { Agnostic Scores } \\
\text { (Baseline Mean: }-0.872 \text { ) }\end{array}$} & \multicolumn{3}{|c|}{$\begin{array}{c}\text { Constrained Scores } \\
\text { (Baseline Mean: }-0.853 \text { ) }\end{array}$} \\
\hline & $(1)$ & $(2)$ & $(3)$ & $(4)$ & $(5)$ & $(6)$ \\
\hline \multicolumn{7}{|l|}{ Panel A: OLS } \\
\hline Change Black Share & $\begin{array}{c}0.008 \\
(0.014)\end{array}$ & $\begin{array}{c}-0.139^{* * *} \\
(0.036)\end{array}$ & $\begin{array}{l}0.049 * * \\
(0.020)\end{array}$ & $\begin{array}{c}0.002 \\
(0.015)\end{array}$ & $\begin{array}{c}-0.150^{* * *} \\
(0.041)\end{array}$ & $\begin{array}{c}0.044^{* *} \\
(0.022)\end{array}$ \\
\hline \multicolumn{7}{|l|}{ Panel B: 2SLS } \\
\hline Change Black Share & $\begin{array}{l}-0.051 \\
(0.039)\end{array}$ & $\begin{array}{c}-0.300^{* * *} \\
(0.116)\end{array}$ & $\begin{array}{c}0.046 \\
(0.056)\end{array}$ & $\begin{array}{l}-0.054 \\
(0.041)\end{array}$ & $\begin{array}{c}-0.337^{* * *} \\
(0.124)\end{array}$ & $\begin{array}{c}0.058 \\
(0.059)\end{array}$ \\
\hline \multicolumn{7}{|l|}{ Panel $C$ : First stage } \\
\hline $\begin{array}{l}\text { Predicted Change } \\
\text { Black Share }\end{array}$ & $\begin{array}{c}1.570^{* * * *} \\
(0.438)\end{array}$ & $\begin{array}{c}1.054^{* * *} \\
(0.377)\end{array}$ & $\begin{array}{c}1.944^{* * *} \\
(0.557)\end{array}$ & $\begin{array}{c}1.553^{* * * *} \\
(0.442)\end{array}$ & $\begin{array}{c}1.050^{* * *} \\
(0.377)\end{array}$ & $\begin{array}{c}1.917^{* * *} \\
(0.564)\end{array}$ \\
\hline F-Stat & 12.87 & 7.814 & 12.19 & 12.35 & 7.770 & 11.57 \\
\hline Observations & 570 & 285 & 285 & 570 & 285 & 285 \\
\hline Congress Period & $78-82 ; 82-88$ & $78-82$ & $82-88$ & $78-82 ; 82-88$ & $78-82$ & $82-88$ \\
\hline
\end{tabular}

Notes: The dependent variable is the change in the civil rights ideology scores from Bateman et al. (2017) "Agnostic" scores in columns 1 to 3, and "Constrained" scores in columns 4 to 6 . Lower (resp. higher) values of the score refer to more liberal (resp. conservative) ideology (see also Bateman et al., 2017, for more details). Columns 1 and 4 (resp. 2-3, and 5-6) estimate stacked first difference regressions (resp. first difference regressions for Congress period 78-82 and 82-88). Panel A reports OLS results and Panel B reports 2SLS results, while Panels C presents first stage estimates. All regressions are weighed by 1940 congressional district population and control for state by year fixed effects and include interactions between period dummies and: i) the 1940 Black share in the congressional district; ii) a dummy for Democratic incumbency in the $78^{t h}$ Congress in the district; and iii) the ideology score in the district in the $78^{\text {th }}$ Congress. First difference regressions do not include interactions with period dummies since these are automatically dropped. F-stat refers to the K-P F-stat for weak instruments. Robust standard errors, clustered at the congressional district level, in parentheses. Significance levels: ${ }^{* * *} \mathrm{p}<0.01,{ }^{* *} \mathrm{p}<0.05,{ }^{*} \mathrm{p}<0.1$. 